University of Nebraska - Lincoln

DigitalCommons@University of Nebraska - Lincoln

USDA National Wildlife Research Center - Staff Publications
U.S. Department of Agriculture: Animal and Plant Health Inspection Service

2019

\title{
Ecological Functions of Vertebrate Scavenging
}

James C. Beasley

Zachary H. Olson

Nuria Selva

Travis L. DeVault

Follow this and additional works at: https://digitalcommons.unl.edu/icwdm_usdanwrc

Part of the Natural Resources and Conservation Commons, Natural Resources Management and Policy Commons, Other Environmental Sciences Commons, Other Veterinary Medicine Commons, Population Biology Commons, Terrestrial and Aquatic Ecology Commons, Veterinary Infectious Diseases Commons, Veterinary Microbiology and Immunobiology Commons, Veterinary Preventive Medicine, Epidemiology, and Public Health Commons, and the Zoology Commons

This Article is brought to you for free and open access by the U.S. Department of Agriculture: Animal and Plant Health Inspection Service at DigitalCommons@University of Nebraska - Lincoln. It has been accepted for inclusion in USDA National Wildlife Research Center - Staff Publications by an authorized administrator of DigitalCommons@University of Nebraska - Lincoln. 


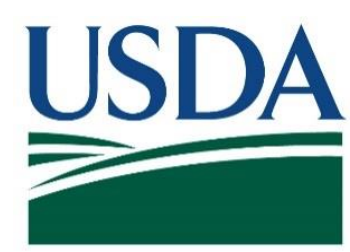

U.S. Department of Agriculture

U.S. Government Publication

Animal and Plant Health Inspection Service

Wildlife Services 


\title{
Ecological Functions of Vertebrate Scavenging
}

\author{
James C. Beasley, Zachary H. Olson, Nuria Selva, and Travis L. DeVault
}

\begin{tabular}{|c|c|}
\hline \multicolumn{2}{|l|}{ Contents } \\
\hline Introduction. .. & 126 \\
\hline Nutrient Recycling........... & 127 \\
\hline Food Web Complexity................... & 127 \\
\hline 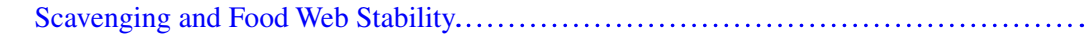 & 128 \\
\hline Scavenging Alters the Trophic Distribution of Carrion-Derived Nutrients.... & 129 \\
\hline Transportation of Carrion Within and Between Ecosystems.................. & 130 \\
\hline Aquatic vs. Terrestrial Systems........................................ & 132 \\
\hline Biodiversity Maintenance........................................... & 133 \\
\hline Obligate and Facultative Scavengers............... & 133 \\
\hline Marine and Terrestrial Examples of Biodiversity... & 135 \\
\hline Disease Control....................................... & 139 \\
\hline Case Studies from Well-Studied Systems. $\ldots \ldots \ldots \ldots \ldots \ldots \ldots \ldots \ldots \ldots \ldots \ldots \ldots \ldots \ldots$ & 140 \\
\hline Midwestern USA: Local Scavenger Guild Diversity and Its Effect on Carrion Removal. . & 140 \\
\hline Białowieża Primeval Forest, Poland: Influence of Carrion Attributes on Scavenger & \\
\hline 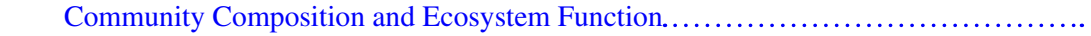 & 143 \\
\hline Yellowstone National Park: Effect of Large Predators on Scavenger Communities & \\
\hline 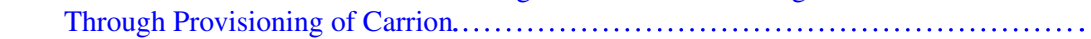 & 146 \\
\hline Impact of Human Activities on Carcass Availability................ & 148 \\
\hline Conclusions and Future Perspectives.................... & 149 \\
\hline 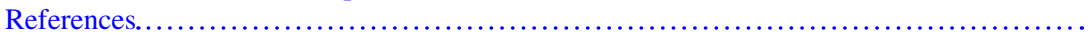 & 150 \\
\hline
\end{tabular}

J. C. Beasley $(\bowtie)$

Savannah River Ecology Lab, Warnell School of Forestry and Natural Resources, University of Georgia, Aiken, SC, USA

e-mail: beasley@srel.uga.edu

\section{Z. H. Olson}

Department of Psychology, University of New England, Biddeford, ME, USA

e-mail: zolson@une.edu

N. Selva

Institute of Nature Conservation, Polish Academy of Sciences, Kraków, Poland

T. L. DeVault

National Wildlife Research Center, Animal Plant Health Inspection Service, Wildlife

Services, U.S. Department of Agriculture, Sandusky, OH, USA

e-mail: travis.1.devault@aphis.usda.gov 


\section{Introduction}

The role of vertebrate scavenging in food web dynamics has historically been minimalized and portrayed as the activity of a select group of obligate scavengers (e.g., vultures), with a simplistic linkage between carrion and detritivores in food webs. Research in the last few decades, however, has revealed that the role of carrion in food web dynamics is severely underestimated, highly complex, and pervasive among ecosystems across the globe (DeVault et al. 2003; Selva and Fortuna 2007; Wilson and Wolkovich 2011). Such observations have led to a surge in research interest in scavenging ecology that continues to reveal new information on the ecological functions of scavenging and the complex role scavengers play in the cycling of nutrients within ecosystems.

Although the functional role of scavengers in ecosystems has been recognized by some ecologists for many years, the importance a single guild of scavengers can have on ecosystem processes was underappreciated by many prior to the collapse of Gyps vulture populations in Asia in the 1990s due to accidental poisoning with diclofenac, a non-steroidal anti-inflammatory drug that was administered to cattle (Oaks et al. 2004). This tragedy has served as a cornerstone example of the ecosystem services provided by scavengers, as well as the potential impacts of anthropogenic activities on ecosystem function (DeVault et al. 2016). Scavengers have historically been some of the most persecuted species across the globe (Ogada et al. 2012a). However, while direct persecution remains a threat to scavengers in some areas, ecosystem services provided by scavengers also are being eroded due to numerous other anthropogenic factors (e.g., climate change, trophic downgrading, habitat loss and fragmentation, contaminants). Many of these factors have far reaching impacts, from the deep sea to arctic ecosystems, and have the potential to disrupt nutrient cycling dynamics across all levels of biological organization.

As a rapidly growing sub-discipline within the field of ecology, substantial advancements continue to be made in our understanding of the role carrion and scavenging play in individual- to ecosystem-level processes (Benbow et al. 2019). In this chapter, we highlight the ecological functions of vertebrate scavenging in both terrestrial and aquatic ecosystems, including those functions that directly benefit humans (i.e. ecosystem services). Specifically, we have delineated specific sections devoted to nutrient cycling, biodiversity maintenance, and disease control, drawing upon examples and case studies from ecosystems across the globe. We also discuss the impact of anthropogenic activities on the availability of carrion within the context of ecosystem functions, as this topic is of growing importance among researchers studying scavenging dynamics. Although substantive progress has been made in our knowledge of scavenging dynamics over the last few decades, there are many aspects of scavenging ecology that remain unanswered and represent important areas for future research. Thus, we conclude the chapter with a brief section highlighting a few areas where additional research is particularly needed to continue advance our understanding of nutrient cycling and scavenging dynamics. 


\section{Nutrient Recycling}

\section{Food Web Complexity}

Scavenging by vertebrates promotes food web complexity, provides routes by which communities may sequester resources at higher trophic levels, and may subsidize particular populations of vertebrates during otherwise food-limited times of the year, resulting in more stable food webs. Food webs are conceptual frameworks used to better understand ecosystems, but many food webs fail to account for trophic connections made through scavenging (Wilson and Wolkovich 2011). For example, early food webs were linear (Elton 1927), which precluded the recognition of many feeding relationships (Lindeman 1942). Later publication of curated food webs (Cohen 1978) and mathematical insights about connections in communities (May 1972) catalyzed a burst of scholarly activity devoted to determining the nature of the relationship between community complexity - that is, the number and strength of links in the food web-and community stability (Dunne 2006).

Yet, despite advancing the stability-complexity debate, these curated food webs (e.g., the cascade model of Cohen et al. 1990) were found to inaccurately characterize ecosystems because they specifically prohibited some categories of real feeding relationships that are commonly expressed as a function of scavenging. In particular, 'loops' were eliminated from a number of notable curated food webs (Pimm 1982; Lawton 1989; Cohen et al. 1990). Loops occur in real food webs because omnivores feed at more than one trophic level (top-down effects) and because consumers receive feedback from the trophic levels they consume (bottom-up effects; Dunne 2006). Thus, loops are an important facet of scavenging ecology, because scavenging facilitates feeding relationships that are typically limited by ecological barriers such as physical size or behaviors like aggression (e.g., see Olson et al. 2016; Turner et al. 2017; chapter "Vertebrate Scavenging Communities").

In counterpoint to the structural limitations of some curated webs, Polis (1991) describes incredibly detailed sub-webs from a desert habitat within the Coachella Valley of California, U.S. Another detailed food web was published by Martínez (1991), this time from a lake in Wisconsin, U.S. Notable differences between these and previous webs included the large number of species, high number of feeding relationships noted for each species, relatively long food chains making up the webs, and frequent observation of looping and omnivory (Polis 1991). Important implications for food web theory aside, Polis (1991) draws particular attention to the fact that connections between species become more numerous when researchers remove the various constraints they had placed on their search for connections. For example, the consideration of parasites as actors in food webs increased food web connectance by $93 \%$ (Lafferty et al. 2006). If, as Polis (1991) argues, there is no good reason to place limits on the feeding relationships that are entered into food webs, the acknowledgement of relationships that occur via scavenging of carrion will also increase complexity of food webs (Wilson and Wolkovich 2011). To take an example from the Coachella Valley food web, lagomorphs (Sylvilagus and Lepus 
spp.) are prey for perhaps 10-15 species throughout life (approximated from Polis 1991). Yet, McKinnerney (1978) noted 63 arthropod and four vertebrates engaged in feeding on experimentally-placed lagomorph carcasses in similar habitats, most of which would have been unaccounted-for links in the food web. The addition of carrion-related connections to food webs creates a large number of loops, both distant and tight. Wilson and Wolkovich (2011) estimated that in 23 well-studied food webs scavenging-related links were underestimated substantially at $1.4 \%$ of links. By considering connections likely to occur based on scavenging behavior, in those same food webs scavenging could have conceivably accounted for $22 \%$ of total links after the adjustment (Wilson and Wolkovich 2011). Clearly, feeding relationships that connect through animal carcasses increase food web complexity.

\section{Scavenging and Food Web Stability}

Although a complexity-stability theory for ecological food webs is not yet fully resolved, two themes have emerged from research on real food webs that support a potential role for scavenging to affect food web stability. Connectance is a measure of link saturation, and refers to the percentage of possible links that are realized in any given food web (May 1972). Food webs with higher connectance have been shown to exhibit greater stability (De Angelis 1975; Dunne et al. 2002). Further, the degree of a food web's nodes - that is, the number of predators and prey connected to each species (Wasserman and Faust 1994)_also influences food web stability, but in a more complicated way. Increased heterogeneity in degree distributions seems to foster a more stable food web (Neutel et al. 2002). Because scavenging results in sometimes unorthodox links between species (DeVault et al. 2003; chapter "Vertebrate Scavenging Communities"), scavenging increases connectance in food webs (Wilson and Wolkovich 2011; Schlichting et al. 2019). Moreover, the degree to which numerically dominant facultative scavengers participate in scavenging behavior varies widely. This variation highlights the fact that many scavenger relationships represent weak links - the very kind of links that influence degree heterogeneity in networks like food webs (McCann et al. 1998; Neutel et al. 2002; DeVault et al. 2003).

Another mechanism by which scavenging may affect food web stability stems from the inherent relationship between food web stability and the population dynamics of its constituent species (Tilman 1996). Few species are obligate scavengers (Ruxton and Houston 2004a), and as ubiquitous as scavenging behavior is at the species level among vertebrate taxa (DeVault et al. 2003), individual facultative scavengers often choose to engage in their preferred foraging method rather than scavenging. Scavenging is often described as a feeding relationship based on need, and as such the importance of scavenging-derived resources is thought to vary dramatically for many species. Gese et al. (1996) found that the ability to scavenge on ungulate carrion was central to coyote Canis latrans activity budgets during winter, particularly if deep snow made travel difficult. In that system, social dominance predicted access to carcasses, because dominant coyotes would sequester fresh car- 
casses and allow lower-ranked individuals access to scavenge only after feeding for several days (Gese et al. 1996). Grizzly bears Ursus arctos horribilis may also depend on carrion during winter, but seem to scavenge in order to replenish energy reserves after emerging from hibernation (Green et al. 1997). Alternatively, scavenging may provide a means for vertebrates to compensate for energeticallyintensive activities such as migration. Bald eagles Haliaeetus leucocephalus follow this example where they have been shown to scavenge salmon Oncorhynchus nerka carcasses plentiful in a particular area along their migration route (Restani et al. 2000). In these situations, scavenging-derived nutrients represent important subsidies for some portion of the population or at some time of the year. Research in scavenging ecology is just beginning to elucidate the exact role that this unique feeding relationship has in maintaining ecosystem stability.

\section{Scavenging Alters the Trophic Distribution of Carrion-Derived Nutrients}

Studying the assemblage of species that feed on a vertebrate carcass provides insights into trophic connections that simply are not present when the animal is alive. If we were to count the number of necrophagy-based links that could be added to food webs based on our knowledge of scavenging by vertebrates (DeVault et al. 2003) and based on our knowledge of decomposition by invertebrates and microbes (VanLaerhoven 2010), the majority of new links - numerically, if not always in terms of overall energy flux-would connect the deceased vertebrate to invertebrates and microbial consumers (i.e., decomposers) rather than to other vertebrates (chapter "Carrion Decomposition"). The numerical importance of invertebrate and decomposer-derived links holds across terrestrial and marine ecosystems (DeVault et al. 2004; Beasley et al. 2012). However, the trend would not be without notable vertebrate exceptions. White-tailed deer Odocoileus virginianus, a large obligate herbivore common across much of North America, have been observed removing small mammal carcasses (Rooney and Waller 2003; DeVault et al. 2011). Because there are no published accounts of deer preying on live small mammals, the deersmall mammal link could be added to the food web only if we considered scavenging to be part of food web theory. Although this particular relationship is probably rare ( 1 in 234 mice based on DeVault et al. 2011), a body of work has emerged that demonstrates the near ubiquity of scavenging behavior across vertebrate taxa (DeVault et al. 2003).

Despite the numerical advantage enjoyed by invertebrate and microbial decomposers at carrion (Janzen 1977; DeVault et al. 2003), vertebrate scavengers are the focus of many investigations. The attention paid to vertebrate scavengers is undoubtedly enhanced by the fact that vertebrates are more easily recognizable than invertebrates or microbes, certainly at the species level, by means of direct (McKinnerney 1978; Hertel 1994; Cortés-Avizanda et al. 2012) or indirect observation (Jędrzejewska and Jędrzejewski 1998; DeVault et al. 2004; Selva et al. 2005; 
Killengreen et al. 2012). Beyond that technical consideration, there are two main arguments for the importance of vertebrate scavenging on ecosystem processes. First, the most frequent scavengers in many systems are also predators (i.e., facultative scavengers; DeVault et al. 2003; Wilson and Wolkovich 2011), and predators have outsized influence on prey and on primary production via trophic cascades (Schmitz et al. 2000). Second, vertebrate scavenging is interesting because of its impact on the flow of carcass resources to the surrounding food web (Wikenros et al. 2013; Beasley et al. 2015). Vertebrate scavenging disproportionately impacts carcass resources, because even one vertebrate scavenger can deny carcass resources a direct path to the detrital pool, thereby maintaining carcass resources at higher trophic levels (Beasley et al. 2015). Simultaneously, vertebrate scavenging preempts or halts the acquisition of carrion resources by invertebrate and microbial decomposers by co-opting the carcass or by ingesting and killing invertebrate and microbial competitors along with the carcass (Janzen 1977; DeVault et al. 2003). The presence or absence of vertebrate scavenging, and the nature of the species doing the scavenging, therefore has important implications for the cycling of nutrients. The importance of vertebrates in determining the fate of individual carcasses is amplified by the fact that most carcasses in many ecosystems are scavenged by vertebrates (DeVault et al. 2003; Mateo-Tomás et al. 2015; Olson et al. 2016; Sebastián-González et al. 2016; chapter "Vertebrate Scavenging Communities").

\section{Transportation of Carrion Within and Between Ecosystems}

While decomposers mostly enhance/promote nutrient recycling into the soil surrounding the carcass, arthropods and vertebrate scavengers contribute to the transport of carrion-derived nutrients (Schlichting et al. 2019; chapter "Carrion Decomposition"). This is mainly done by consuming carrion and later producing excretions away from the carcass, but also by transporting parts of the carcasses. Although some arthropods can take away carcass portions, e.g. some carrion beetles Necrophorus spp. may roll and bury a carrion ball, vertebrate scavengers are mainly responsible for transport of carrion at longer distances. Many scavengers have been documented caching carrion in presumably less risky places and later returning to retrieve and consume the carcass (Magoun 1976; Selva 2004a). In Białowieża Forest, carrion retrieval was recorded in the jay Garrulus glandarius, raven Corvus corax, white-tailed eagle Haliaeetus albicilla, fox Vulpes vulpes, and pine marten Martes martes; wolves Canis lupus were often documented carrying carcass pieces few kilometers away from the kill. Caching meat is common among ravens and other corvids as well as many mammalian carnivores, and seems to be more widespread among scavengers at higher latitudes (Heinrich and Pepper 1998; Selva 2004a).

One of the most notable examples of carrion transport between ecosystems is the annual return of spawning salmon from the sea to the rivers, which represents a pulsed resource of marine nutrients into freshwater and terrestrial systems 


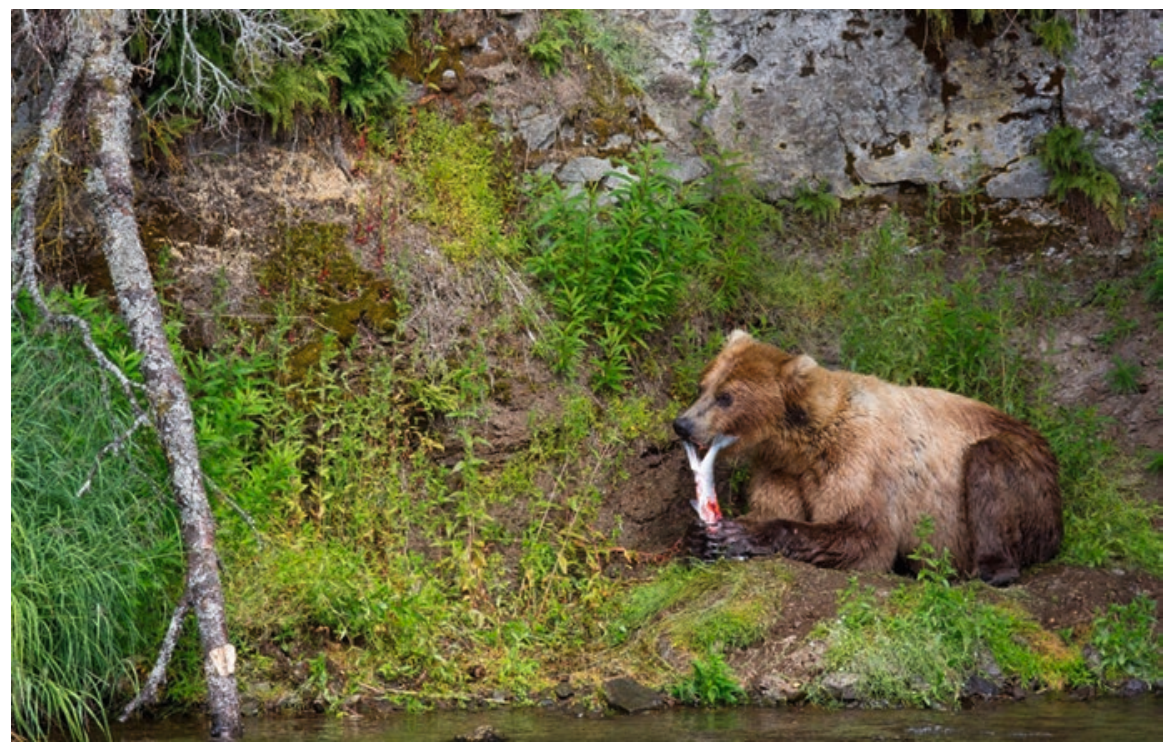

Fig. 1 Salmon are a notable example of carrion transport between ecosystems, representing a pulsed resource of marine nutrients into freshwater and terrestrial systems. Photo credit: Adam Wajrak

(Cederholm et al. 1999; Gende et al. 2002). Salmon carrion "fertilizes" streams and provides high-quality food for fishes a nd i nvertebrates. $\mathrm{S}$ almon, $\mathrm{b}$ oth a live a nd dead, are also consumed by a wide range of terrestrial vertebrates, including bears, wolves, coyotes, and numerous avian scavengers, and by a diverse community $(>60$ species) of terrestrial invertebrate decomposers (Hocking et al. 2009; Levi et al. 2015). Among salmon consumers, brown bears Ursus arctos are a keystone species for the transfer of salmon carrion and nutrients into adjacent forest (Fig. 1). After capturing salmon in the rivers, brown bears move to the adjacent land to feed on energy-rich portions, leaving for scavengers carcasses from the salmon they kill which are only partially consumed (Gende et al. 2004). Bear foraging and other scavengers' activities play a crucial role in making salmon-derived nutrients available to terrestrial vegetation and subsidizing the forest. Indeed, the salmon-bear interaction can provide up to $24 \%$ of riparian nitrogen $(\mathrm{N})$ budgets (Helfield and Naiman 2006).

The transfer of marine carrion into adjacent lands is often mediated by scavengers. For example, seal (Phocidae) carrion may subsidize Arctic foxes Vulpes lagopus in Canada during low-density phases of the cyclic lemming Dicrostonyx richardsoni population (Roth 2003). Marine carrion reaching the coast also supported higher densities of coyotes in desert areas of California (Rose and Polis 1998). These allochthonous carrion inputs to scavengers exert notable effects on bottom-up regulation, top-down control and the complexity and structure of trophic interactions (Rose and Polis 1998). (see chapter "Carrion Availability in Space and Time" on Carrion Exchange at the Terrestrial-Aquatic Interface). 


\section{Aquatic vs. Terrestrial Systems}

The fundamental processes of decomposition and scavenging are similar among ecosystems across the globe, with a diverse assemblage of microorganisms, invertebrates, plants, and vertebrates playing critical roles in the assimilation and redistribution of nutrients within the ecosystem. However, the composition and functional role of each of these groups can vary widely among ecosystems, as well as the resulting spatial and temporal diffusion of carcass nutrients, processes ultimately driven by fundamental differences in both abiotic conditions and emergent properties of air and water (Beasley et al. 2012).

In particular, the three-dimensional nature of aquatic ecosystems facilitates the movement of carrion by wave action, upwelling, and sinking, diffusing the nutrients within carrion sources across a much larger spatial scale than occurs in terrestrial ecosystems (Britton and Morton 1994). This diffusion of nutrients is most dramatically recognized in pelagic ocean habitats where disparate scavenging communities exist between the photic zone (where most nutrient production and sources of carrion occur) and organisms living in the benthic zone, where the existence of deepsea scavengers is inextricably linked to productivity of nekton (i.e. raining organic matter) from the surface (Gooday et al. 1990; Britton and Morton 1994; Smith et al. 2008). Thus, the redistribution of nutrients sequestered in carcasses within aquatic ecosystems is complex and largely depends upon the speed of vertical dissemination of carrion through the water column. Carcass particulates can be even more mobile than whole carcasses, dispersing tens to hundreds of kilometers or more within aquatic ecosystems through wave action and diffusing aquatic carrion across vast spatial scales in three-dimensional space.

In contrast, within terrestrial ecosystems the processes of scavenging and decomposition are primarily localized around the origin of the carrion resource, creating a tight linkage between processes of nutrient production, scavenging, and decomposition in terrestrial ecosystems that is absent in many aquatic ecosystems (Wardle et al. 2004). Such localized concentrations of resources, even when scavenged, can create biogeochemical hotspots within terrestrial soils that alter the nutrient composition of forest soils, influencing the growth and species composition of local plant communities for years (Bump et al. 2009a, Hocking and Reynolds 2011; Barton et al. 2013; chapter "Carrion Decomposition"). Similar analogs also exist in benthic ecosystems where, once settled on the sea floor, large carrion falls (e.g., whalesCetacea) create a localized flux of organically-enriched sediments surrounding carcasses that are colonized by dense assemblages (e.g., up to 40,000 per $\mathrm{m}^{2}$ ) of crustaceans and annelid worms; although such enrichment of sediments does not appear to occur for carcasses $<50 \mathrm{~kg}$ in size (Smith and Baco 2003).

However, even within terrestrial ecosystems food-web linkages between scavenging guilds can vary widely among ecosystems, primarily due to underlying differences in abiotic conditions (e.g., temperature, rainfall). Such differences are particularly pronounced when comparing arctic and tropical ecosystems, although a latitudinal gradient undoubtedly exists in the role of microbial, invertebrate, and 
vertebrates in the assimilation of carrion; gradients affecting guild membership also are pronounced between humid and arid environments (Parmenter and MacMahon 2009). Aquatic ecosystems (particularly benthic habitats), in contrast, are buffered to some degree by temporal changes in weather, potentially minimizing seasonal or even daily fluctuations in competitive interactions and nutrient assimilation between microbes, invertebrates and vertebrates that exists in terrestrial ecosystems (DeVault et al. 2003; Beasley et al. 2015). Such competitive interactions and consistency among guilds involved in recycling of carrion nutrients is further modulated by reduced temperatures in benthic ecosystems, which minimizes the role of bacteria in the redistribution of nutrients (Beasley et al. 2012). Thus, despite the similar functional role of the redistribution of carrion nutrients within food webs, the strength and consistency of individual linkages can vary widely among ecosystem types, complicating our understanding of food web dynamics and the impacts of anthropogenic activities upon such processes.

\section{Biodiversity Maintenance}

\section{Obligate and Facultative Scavengers}

Although most, if not all, carnivorous animals will eat carrion under certain conditions (DeVault et al. 2003; Fig. 2), some species rely heavily on carrion and thus are often referred to as scavengers rather than predators (chapter "Vertebrate Scavenging Communities"). Adaptations attributed to a scavenging lifestyle include rapid and efficient locomotion to locate an ephemeral and sometimes unpredictable food supply, well developed visual and/or olfactory senses, a large body size to withstand periods of food shortage, and the ability to withstand or detoxify products of microbial decomposition (Houston 1979; Ruxton and Houston 2004a, Shivik 2006). There appears to be a continuum of species with varying levels of adaptation for finding and consuming carrion (DeVault et al. 2003), and even within species some individuals scavenge more than others (Shivik and Clark 1999).

Despite this continuum, scavenging animals are generally classified as either obligate (species that scavenge exclusively) or facultative (predators that also occasionally scavenge, i.e., most carnivorous vertebrates) (chapter "Vertebrate Scavenging Communities"). Most researchers agree that the only terrestrial obligate scavengers are the Old and New World vultures (families Accipitridae and Cathartidae) (DeVault et al. 2003; Beasley et al. 2015). Indeed, even terrestrial species such as coyotes and spotted hyenas Crocuta crocuta, which are generally considered to be excellent scavengers, obtain most of their food by killing live prey (Gasaway et al. 1991; Linnell et al. 1995). In contrast, a great deal of discussion has been devoted to the question of whether aquatic obligate scavengers exist (e.g., Britton and Morton 1994; Kaiser and Moore 1999; Ruxton and Houston 2004b, Ruxton and Bailey 2005). Regardless of whether some aquatic species are able to 

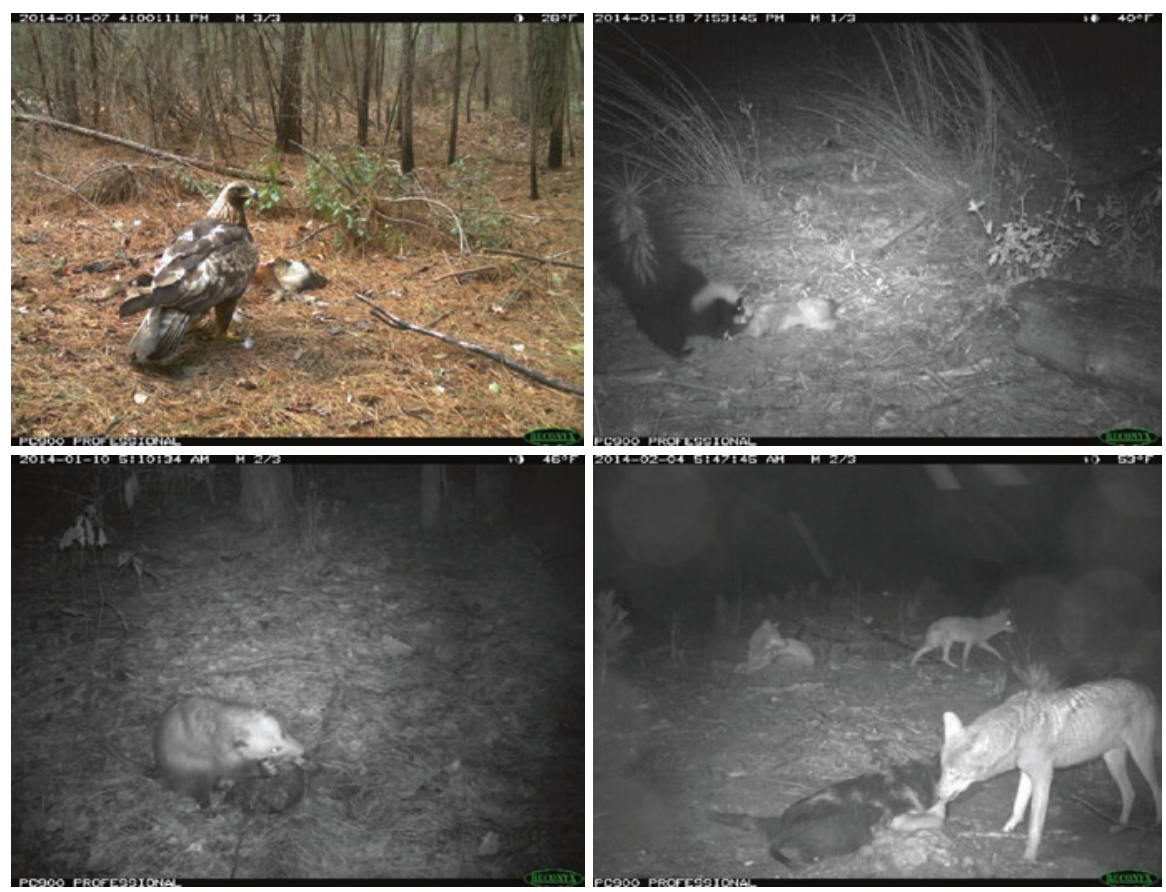

Fig. 2 Although vultures are globally recognized as important vertebrate scavengers, there is growing evidence that most vertebrates will opportunistically scavenge carrion when available. Facultative scavengers in Midwestern USA (clockwise) include golden eagle (Aquila chrysaetos), striped skunk (Mephitis mephitis), Virginia opossum (Didelphis virginiana), and coyotes (Canis latrans). Photo credit: Kelsey Turner and James Beasley

survive solely on carrion, it is clear that some are extremely well adapted for scavenging, having acute chemoreception, efficient locomotion, and being able to withstand long periods of food shortage (Tamburri and Barry 1999; Smith and Baco 2003). Additionally, the question of obligate scavenging has been argued with respect to long-extinct species (e.g., Tyrannosaurus rex; Ruxton and Houston 2003; Carbone et al. 2011).

Seemingly lost in discussions of "scavenger" vs. "predator" is the fact that even the clearest examples of obligate scavengers_-vultures_-occasionally kill and eat other animals, especially relatively helpless, newborn livestock (Lowney 1999; Avery and Cummings 2004; Margalida et al. 2014). It seems unreasonable that any carnivorous animal would choose not to kill and consume vulnerable prey, especially when carrion is scarce. Along these lines, we suggest that some well-adapted aquatic scavengers (e.g., hagfish; family Myxinidae) are likely just as "obligate" as many species of vultures (chapter "Vertebrate Scavenging Communities"), and that such classification exercises are generally unhelpful. Many terrestrial and marine organisms have developed mechanisms to survive largely, if not exclusively, on carrion, showing the importance of necrophagy to their livelihood. 


\section{Marine and Terrestrial Examples of Biodiversity}

Carrion is a nutrient rich resource utilized by a diverse array of facultative and obligate scavengers across the globe and thus plays a critical role in shaping species diversity and nutrient cycling within ecosystems (Barton et al. 2013; chapters "Invertebrate Scavenging Communities", "Vertebrate Scavenging Communities", and "Carrion Decomposition"). Moreover, carrion can affect the composition of local soil (Melis et al. 2007; Bump et al. 2009a, b, Parmenter and MacMahon 2009), microbial (Yang 2004), arthropod (Melis et al. 2004), and plant (Towne 2000) communities and thus can have substantive effects on biodiversity and function within ecosystems. Such widespread use of carrion resources among levels of biological organization has led to intensive inter-kingdom competition for acquisition of nutrients sequestered within carrion resources. This competition has resulted in intensive selection pressure on many species that utilize carrion resources.

For example, some species of arthropods have evolved highly sensitive chemoreceptive abilities allowing them to locate vertebrate carrion resources at the time of, or soon after, death (Tomberlin et al. 2005). Oviposition by these flies is further influenced by complex interactions with microbes that dictates attraction and repulsion of conspecifics to a carcass and plays an important role in survivorship of deposited eggs (Lam et al. 2007; Zheng et al. 2013). Similarly, intensive intra- and interspecific competition exists among burying beetles for access to a carcass as larvae from a single clutch can consume an entire carcass (Müller et al. 1990). Among vertebrates, vultures are the most well-known exemplars of species with adaptations conducive of a scavenging lifestyle, with each species exhibiting unique adaptations to minimize niche overlap for a sparse and unpredictable food source. For example, although both black Coragyps atratus and turkey vultures Cathartes aura overlap extensively in distribution, both species have evolved disparate chemoreceptive abilities, social behavior, and flight ability (Kirk and Mossman 1998; Buckley 1999). Similarly, bearded vultures Gypaetus barbatus have evolved for specialized feeding on bone marrow and bones of animal carcasses to minimize interspecific competition with other old world vultures that primarily consume flesh (Margalida et al. 2009). However, adaptations that facilitate the detection (e.g., mobility, chemoreception) or reliance (e.g., fasting ability) on carrion are pervasive among terrestrial and aquatic vertebrate communities.

Regardless of ecosystem type, carrion is patchily distributed in both space and time, creating heterogeneity in community richness and composition. The spatial and temporal extent of such effects are largely influenced by the physical properties of carcasses (e.g., size), environmental conditions (e.g., temperature, humidity), and ecology (e.g., energy requirements, home range size, reliance on carrion resources) of scavenging guilds (DeVault et al. 2003; Moleón et al. 2015; Turner et al. 2017; chapter "Carrion Availability in Space and Time"). For example, a single small mammal carcass likely has a much more profound effect on the nutritive status of small- vs. large-bodied facultative scavengers (e.g., red fox vs. brown bear). Similarly, the influence of carrion on the survival and reproduction of facultative 
scavengers likely differs geographically as a function of ecosystem productivity, with the most profound effects of carrion resources occurring in the arctic or other landscapes with reduced vertebrate diversity (Fuglei et al. 2003). However, the role of carrion subsidies to survival and reproduction is largely unknown for most facultative scavengers.

Carcasses alter concentrations of inorganic $\mathrm{N}$ and phosphorous (P) in local soil, increasing the species richness and diversity of surrounding plant communities (Towne 2000; Parmenter and MacMahon 2009). Although such effects may be more pronounced for larger vertebrate carrion at a local scale, smaller vertebrates are often more abundant and thus likely equally significant in their contribution to nutrient cycling and dynamics at the landscape scale. For example, in portions of their invasive range coqui frogs Eleutherodactylus coqui can reach densities of $>91,000$ adult frogs/ha (Beard et al. 2009) and their carcasses are readily scavenged by vertebrates (Abernethy et al. 2016). Similarly, rodents, amphibians, invertebrates and other small organisms can achieve remarkably high densities in some ecosystems and thus represent large pools of potential carrion. Such influxes of nutrients through carrion (even scavenged carrion) create biogeochemical hotspots in local soils that alter plant community dynamics and thus aid in maintaining plant biodiversity by creating heterogeneity in resource availability throughout the landscape (Bump et al. 2009a). Shifts in abundance and community diversity at carcass sites also are observed in microbial and fungal communities where up to a $400 \%$ increase in microbial biomass has been observed in soil under a single rat Rattus rattus carcass (Bump et al. 2009b, Barton et al. 2013).

Aside from microbial communities, arthropods are generally the most abundant and species diverse group of organisms at a carrion source and their influence on decomposition processes can be profound (Barton et al. 2013; Pechal et al. 2014). Moreover, among biological communities that utilize carrion, niche separation and specialization across a multitude of carrion resources is probably most prevalent within the invertebrate community. Vertebrate carcasses can be further broken down into disparate components (e.g., flesh, skin, fluids, stomach content, hooves and horns), each of which can serve as a unique attractant to a diverse assemblage of invertebrate scavengers (Braack 1987; chapter "Invertebrate Scavenging Communities"). Of these, carcasses are dominated by soft tissues and thus such tissues support the greatest biomass and diversity of attendant arthropods. In particular, blow-fly larvae can achieve numbers in excess of 200,000 on a single carcass, dominating carcass colonization and biomass consumption of soft tissue, especially during warmer months (Payne 1965). Such competition for carrion resources has led to the evolution of a diverse community of species able to take advantage of other animal components such as rumen content (e.g., Scarabaeidae, Muscidae), skin (e.g., Dermestes maculatus), keratinized tissues (e.g., Ceratophaga vastella, trogid beetles), and remaining detritus following consumption of carcasses (e.g., ants) (Braack 1987). In addition, numerous invertebrate species (e.g., Histerid beetles) utilize carrion indirectly by preying on other invertebrates, particularly blowfly larvae at carcasses (see chapter "Invertebrate Scavenging Communities"). Such concentrations of invertebrates at carcasses is further exploited by parasitic species 
(e.g., parasitic wasps-Diapriidae, Pteromalidae), that target developing pupae (Braack 1987). Thus, carcass sites represent hotspots of invertebrate biodiversity that facilitate the maintenance and propagation of species diversity within invertebrate communities.

Such competition among invertebrates for resources sequestered within carrion is further enhanced through competition with vertebrates. In some ecosystems, vertebrates may assimilate as much as $90 \%$ of the available carrion and thus there is an intensive inter-kingdom "arms-race" for carrion resources that is driving the evolution of species reliant upon carrion (DeVault et al. 2003, 2011). Although only a few groups of vertebrate taxa have evolved as obligate scavengers (see above), nearly all vertebrates will utilize carrion opportunity and can be considered facultative scavengers (DeVault et al. 2003; Beasley et al. 2015). This propensity to scavenge underscores the importance of scavenging-derived nutrients in vertebrate communities and suggests scavenging behavior may have profound effects on food web stabilization (Wilson and Wolkovich 2011). Despite the growing awareness of the pervasiveness of scavenging among vertebrates across a wide range of taxa and ecosystems, the influence of carrion on survival and reproduction are largely unknown for many facultative scavengers, although such effects are potentially profound, particularly in resource-limited ecosystems.

The sequential colonization and use of carcasses by invertebrates has been well documented (Byrd and Castner 2010). Such patterns are sufficiently predictable and they represent a cornerstone of forensic investigations regarding time of death (chapter "Invertebrate Scavenging Communities"). Temporal heterogeneity in carcass use by vertebrates does not appear to be as predictable or prevalent, although there is recent evidence of some temporal partitioning in arrival times between sympatric black and turkey vultures, likely due to differences in their natural history (Beasley, unpublished data). Rather, spatial or temporal variation in carcass use by vertebrate species is likely more heavily influenced by local densities, abiotic factors, and community assembly (Selva and Fortuna 2007; Sebastián-González et al. 2013; Allen et al. 2014).

Succession among scavenging communities utilizing carrion is especially pronounced in deep sea ecosystems due to low temperatures, increased pressure, and reduced microbial activity (Smith and Baco 2003; chapter "Methods for Monitoring Carrion Decomposition in Aquatic Environments"). Although few studies have quantified community composition and succession at carcasses in abysmal ecosystems, observations at large cetacean carcasses suggest a single carcass can provide a nutrient-rich food source to hundreds of thousands of scavengers comprising nearly 200 species, lasting up to several years (Smith and Baco 2003). In contrast, large vertebrate carrion in terrestrial ecosystems can be assimilated by insects and microbes within days or months (Coe 1978; Selva et al. 2003; Carter et al. 2007). Thus, despite the spatio-temporal unpredictability of carrion in vast marine ecosystems, the persistence of carrion due to reduced microbial activity appears to be an important contributing factor to the evolution and maintenance of a diverse array of species in these ecosystems by broadening the range of niche space (Butman et al. 1995). 
In particular, large cetacean carcasses clearly serve as hotspots of biological diversity within deep-sea ecosystems, the effects of which may last for decades (Smith and Baco 2003). Such carcasses have been hypothesized to serve a critical role as dispersal stepping stones for some deep sea vent and seep fauna and there is evidence some species may in fact be whale carcass specialists (Smith and Baco 2003). Whales can provide hotspots of activity even among large apex predators. For example, Fallows et al. (2013) observed up to 40 white sharks Carcharodon carcharias feeding on an individual whale carcass in a single day, with more than 5 individual sharks scavenging on the carcass in over $50 \%$ of their observational days. In addition to whale carcass specialists, there also is evidence to support the evolution of additional carrion specialists in marine ecosystems such as bone-eating Osedax worms (Rouse et al. 2004) and bone-eating Rubyspira snails (Johnson et al. 2010).

\section{Creation of Localized Hotspots of Biodiversity}

Because carrion is such an energy- and nutrient-rich resource, the availability of a carcass marks the beginning of an intense competition among microbes, invertebrates, and vertebrates to sequester carrion resources (DeVault et al. 2003). There are several attributes of carrion that might serve to maintain biodiversity in ecosystems. First, carrion is an ephemeral resource that is quickly attenuated (Coe 1978). The fast reduction time of dead animal matter is likely due to the fact that animal bodies represent one of the highest concentrations of $\mathrm{N}$ and $\mathrm{P}$ in ecosystems (Cornaby 1974; Swift et al. 1979; Carter et al. 2007). Rapid attenuation of carrion means that the resource is not ubiquitously available, at least at the level of an individual consumer (Ruxton and Houston 2004a). The individual consumer therefore perceives carrion as unpredictable in space and time (Wilmers et al. 2003a). Resource unpredictability is an important factor in biodiversity maintenance, because unpredictable resources are unlikely to be monopolized by a particular consumer (Cortés-Avizanda et al. 2012). Even the highly specialized, obligate scavenging vertebrates lose some of every carcass to combinations of microbes, invertebrates, and facultative vertebrate scavenger competitors (DeVault et al. 2003). Second, if carrion was a homogenous resource, the principle of competitive exclusion would suggest that it would be impossible for carrion to host the diverse field of consumers that are known to use it for food and reproduction (VanLaerhoven 2010). Rather than being used as homogenous resources, carcasses are partitioned by carrion obligate scavengers (Kruuk 1967); each species working to extract resources from their own realized niche (Hutchinson 1957). For example, past and present vulture assemblages are comprised of animals with different specialties in terms of their feeding strategy at carcasses (Hertel 1994; Houston 1979), and invertebrate species also partition carcasses by concentrating on particular areas or tissues (McKinnerney 1978; Hanski and Kuusela 1980). Carrion as a resource is defined as being rich in energy and nutrients, unpredictable in space and time, ephemeral where it occurs, and heterogeneous in composition, a list of properties that has primed carrion resources to be the focus of competitions that have shaped a number of species' evolutionary histories. Carrion itself provides 
niche space through these competitive interactions that result in its hosting remarkable biodiversity, but carrion effects are not limited to the confines of the carcass.

Unless preserved after death, carcasses enter a linear and predictable sequence of stages leading to their reduction (Carter et al. 2007). Whether a carcass undergoes carrion decomposition on the one hand or carrion removal by vertebrates on the other represent a branching point for carrion nutrients in the ecosystem. In the absence of vertebrate scavenging, decomposition by microbes and invertebrates retains many carcass nutrients in situ. Carcass leachates created by (or released by) microbe and invertebrate action enrich the soil surrounding the carcass and aide in the formation of nutrient-abundant cadaver decomposition island (Carter et al. 2007). Carcass nutrients are then available for use by whole assemblages of soil microbes in addition to the nearby plant community (Melis et al. 2007; Bump et al. 2009a; see chapter "Carrion Decomposition" for more details on carrion decomposition).

Vertebrate scavengers can dramatically affect the outcome, this linear and predictable trajectory, of decomposition by removing (consuming) carrion resources. Carrion removal by vertebrates halts decomposition, halts the formation of a cadaver decomposition island (Carter et al. 2007), prevents the flush of nutrients to nearby soil and foliar communities, and generally disrupts the localized burst of biological activity that coincides with a decomposing carcass (Bump et al. 2009b; Beasley et al. 2015). Therefore, carrion can provide an intense resource pulse to nearby soil and foliar networks, causing a flush of growth in nearby plants and population growth in the soil microbiome (Wilson and Wolkovich 2011). Alternatively, carrion can be removed by vertebrate scavengers, mitigating further competitive interactions for carcass resources as the vertebrate monopolizes remaining resources and predates entire assemblages of microbial and invertebrate carcass colonizers (Polis 1991). In this way vertebrate scavenging strongly influences the biodiversity associated with carrion resources, and likely has influenced the evolutionary arms race that has produced so much biodiversity at carcass resources (DeVault et al. 2003).

\section{Disease Control}

Many authors have speculated on the role of scavenging in disease ecology (see Bellan et al. 2013 and references therein), but until recently few studies had considered how scavengers affect the spread of pathogens across landscapes (see chapter "The Role of Scavenging in Disease Dynamics"). Superficially, it would seem that scavengers could potentially proliferate diseases across large areas: animal carcasses can serve as hotspots for infectious materials, and scavengers often have large home ranges, foraging at widely-spaced carcasses (e.g., Houston 1979; DeVault et al. 2004). Many scavengers can visit a single large carcass before advanced decomposition (Jennelle et al. 2009). Also, at least some infectious materials can survive the digestive process of certain scavengers (VerCauteren et al. 2012). On the other hand, scavengers could reduce carcass-derived pathogens. Well 
adapted scavengers are often highly resistant to disease (Shivik 2006). For example, griffon vultures have highly acidic stomachs ( $\mathrm{pH}$ of $1-2)$, which most pathogenic bacteria are unlikely to survive (Houston and Cooper 1975). Further, black and turkey vultures have extremely selective gastrointestinal tracts and most bacteria are killed during the digestive process (Roggenbuck et al. 2014).

Recent studies suggest that the composition of the scavenging community can strongly influence disease dynamics from carrion (Beasley et al. 2015). Ogada et al. (2012b) excluded African vultures from experimental carcasses and found that carcass persistence tripled, with resulting increased carcass use by mammals. Contacts between mammals at carcasses also increased in the absence of vultures, maximizing the probability of disease spread (Ogada et al. 2012b). Similarly, Hill et al. (2018) observed a >tenfold increase in the number of rabbit carcasses not fully scavenged among vulture-excluded carcasses. The dramatic decline of vultures in south Asia (caused by unintentional poisoning; Green et al. 2004; Oaks et al. 2004) also demonstrated how changes in the vertebrate scavenger community can influence disease. In the near-complete absence of vultures, human health costs from rabies increased dramatically (Markandya et al. 2008), apparently due to increased use of large carcasses by feral dogs and rats and subsequent population increases (Pain et al. 2003; Prakash et al. 2003).

It is clear that vertebrate scavengers can substantially influence disease dynamics. Under certain conditions, scavengers can facilitate the spread of some diseases, or alternatively, reduce carcass-derived pathogens across landscapes. Research suggests that the composition of the vertebrate scavenger community (e.g., one dominated by vultures vs. mammals) can mediate disease proliferation (e.g., Markandya et al. 2008; Ogada et al. 2012b). However, the role of vertebrate scavengers in disease dynamics is a fledgling area of study. Future research should examine the abiotic and biotic conditions that regulate the movement and propagation of carcass-derived pathogens within and across landscapes (see chapter "The Role of Scavenging in Disease Dynamics" for more information on the role of scavenging in disease dynamics).

\section{Case Studies from Well-Studied Systems}

\section{Midwestern USA: Local Scavenger Guild Diversity and Its Effect on Carrion Removal}

The midwestern United States is best described as a human-dominated landscape (Fig. 3a). Habitat fragmentation is severe with development sprawl, road networks, and mechanized agriculture serving to reduce overall habitat area and connectivity for wildlife species (Moore and Swihart 2005). Scavenging trials were conducted in northcentral Indiana, a state in the Midwestern US, to explore scavenging ecology in human-dominated landscapes. The original natural habitat across much of the Midwestern US and in Indiana was forest. However, fragmentation has reduced the 

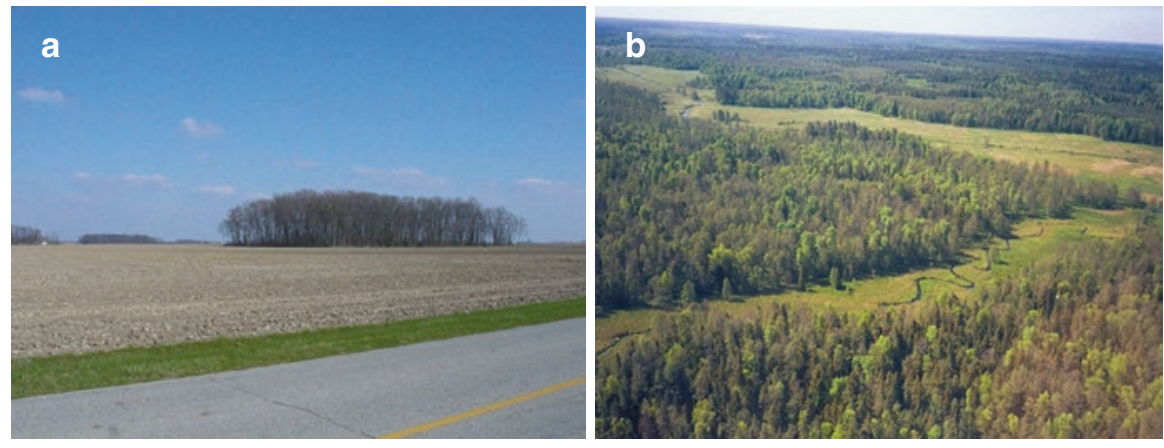

Fig. 3 (a) Example of a a highly fragmented agricultural ecosystem where vertebrate scavengers are often concentrated within remnant native habitat interspersed within a matrix of agriculture. Explore the area through Google Street View by clicking on https://goo.gl/maps/ZB5FW22iRUL2. (b) The Białowieża Primeval Forest along the Polish-Belarussian border, which is one of the best preserved European lowland temperate forests of its size. The Białowieża Primeval Forest (https:// goo.gl/maps/Hb7DKihP8tk) is inhabited by a diverse animal community, including 5 species of ungulates and 40 species of raptors and carnivores. Photo credits: James Beasley (left) and Nuria Selva (right)

natural forest habitat into small patches referred to as woodlots. The woodlots in this study system acted essentially as habitat islands in a matrix of row crop agriculture and human development. Woodlots were small in general: 50\% of forested habitat on the landscape exists in patches $<2$ ha in size, $75 \%$ exists in woodlots $<5$ ha in size, and only $1 \%$ of all forested habitat exists in woodlots $>100$ ha (Moore and Swihart 2005). From an ecological perspective, the landscape is inhabited by a truncated vertebrate fauna consisting mainly of those species that could adapt to a pervasive human presence. Top predators have been extirpated since at least the early 1900s (Whitaker and Mumford 2010), leaving a guild of mesopredators in their stead. Populations of some generalist mesopredators such as the Virginia opossum Didelphis virginiana and raccoon Procyon lotor have flourished for a number of reasons and have reached tremendous abundances (Beasley et al. 2011).

The pervasive ecological effects of such highly abundant mesopredator populations translated readily to affect scavenging ecology. When comparing the proportion of small mammal carcasses removed by vertebrates in the fragmented Midwestern study site to that in an intact, forested landscape in the southeastern US, the vertebrate scavenger community was much more efficient in the Midwest (Fig. 4a). Moreover, raccoon and opossum scavenging was responsible for removing nearly all of vertebrate-consumed small mammal carcasses in the Midwestern study site with a guild richness of just nine species (Fig. 4b; DeVault et al. 2011). In the intact southeastern US study site the vertebrate scavenger guild exhibited greater evenness (although raccoons and opossums still removed the majority of carcasses; DeVault et al. 2004) and a much greater scavenger guild richness ( $\mathrm{N}=17$ species; Fig. 4b). Carrion removal in the fragmented Midwestern study system was effectively dominated by the highly abundant raccoon and opossum populations (DeVault et al. 2011). 

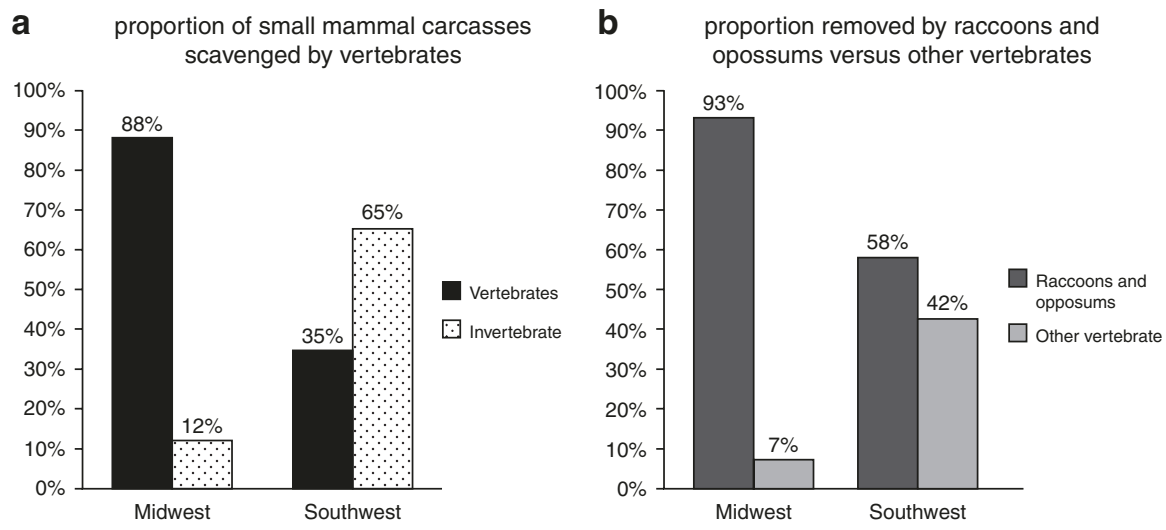

Fig. 4 (a) Proportion of small mammal carcasses removed by vertebrates and (b) the proportion removed specifically by raccoon (Procyon lotor) and Virginia opossum (Didelphis virginiana) relative to other vertebrates in the fragmented Midwestern USA study site compared to that in an intact, forested landscape in the southeastern USA. Credits: the chapter authors

Numerical and ecological dominance of mesopredators in the fragmented study system presented a unique opportunity to test the stability of ecosystem service provisioning under an altered scavenger fauna. To that end researchers removed the dominant scavenger, raccoons, from 13 woodlots and retained intact communities in 13 additional control woodlots (Olson et al. 2012), and then conducted scavenging trials using small mammals as carrion. Raccoons were allowed to recolonize removal woodlots naturally, but recolonization was still ongoing 3 years postremoval (Beasley et al. 2013). Given the behavioral plasticity of mesopredators (Prugh et al. 2009) and ecosystem-level efficiency of carcass removal in general (DeVault et al. 2003), it was hypothesized that any reduction in raccoon scavenging resulting from the experiment would be offset by a functional response in the nextmost-dominant scavenger, the opossum. In other words, it was thought that opossums would be poised to take up any additional carcasses if carcass availability increased, and that invertebrates would claim any carcasses that the opossums did not remove. What was found instead was rather surprising.

Neither opossums nor invertebrates increased the proportion of carcasses they consumed in treatment (i.e., raccoon removal) woodlots relative to the proportion they consumed in control woodlots. This stability of carrion consumption by opossums and invertebrates occurred in juxtaposition to a $>50 \%$ decline in raccoon scavenging in removal woodlots relative to control woodlots (i.e., the experimental effect). Interestingly, the number of carcasses that remained un-consumed at the ends of trials increased in those woodlots where raccoon scavenging was experimentally reduced relative to the control woodlots. Thus, an experimental alteration of the scavenging fauna resulted in a slight decrease in the efficiency with which carrion removal occurred on the landscape (Olson et al. 2012). The fact that the delivery of an important ecosystem service, carcass removal, could be altered by such a perturbation in a generalist-heavy ecosystem was not expected. 
Given the importance of raccoons and opossums to the study system, and the large effect that fragmentation has on ecosystems (Fahrig 2003), additional work in the system focused on understanding how local scavenger guilds responded to raccoon and opossum carcasses in the context of landscape connectivity. Researchers deployed raccoon, opossum, and domestic rabbit carcasses into woodlots with high, intermediate, and low levels of habitat connectivity on the landscape (Olson et al. 2016). In this way the researchers could determine if carcass type or habitat connectivity was more influential in affecting facets of scavenging and carcass removal. In keeping with the efficiency of the scavenging guild in this Midwestern US study area, the vast majority ( $87 \%$ ) of carcasses were scavenged at least in part by vertebrate scavengers. Invertebrates monopolized some (10\%) carcasses during warmer weather and a small portion $(3 \%)$ of carcasses went untouched through the experiment. Opossums occurred as scavengers most frequently in the study, making up $29 \%$ of all scavenger activity. In contrast to trials using small mammals as carrion, obligate scavenging turkey vultures accounted for the next-highest level of scavenger activity (17\%) whereas raccoons accounted for $14 \%$ of scavenger activity. Vertebrates scavenging at frequencies $\geq 5 \%$ also included the red-tailed hawk (13\%; Buteo jamaicensis), American crow (10\%; Corvus brachyrhynchos), and coyote (5\%), with overall guild richness of 15 species. The larger carcasses (2-6 kg) were not dominated by mesopredator scavenging to the extent that smaller carcasses (12$24 \mathrm{~g}$ ) were in the same system.

Local scavenger guild richness was in line with that reported in other studies, between 2 and 3 scavengers on average, but was 24\% lower for opossum carcasses than for raccoon carcasses with rabbits exhibiting no difference from other carcass types. At the same time, local scavenger guild richness was similar across categories of habitat connectivity. Similarly, beta diversity of local scavenger guilds was more affected by carcass type than habitat connectivity. Focusing on the process of carrion removal, the researchers found that each additional vertebrate scavenger that occurred at a carcass increased the proportion of the carcass that was consumed by $6 \%$ on average. From these findings, the researchers concluded that differences in carrion utilization exist among carcass types, these differences were not necessarily related to initial carcass mass, and that the reliability of carcass removal as an ecosystem service depends on the existence of a robust vertebrate and invertebrate community.

\section{Białowieża Primeval Forest, Poland: Influence of Carrion Attributes on Scavenger Community Composition and Ecosystem Function}

The Białowieża Primeval Forest (ca $1450 \mathrm{~km}^{2}$, Polish-Belarussian border) is one of the best preserved European lowland temperate forests of its size (Fig. 3b). The forest, which is fairly flat (135-202 $\mathrm{m}$ a.s.1.) and sparsely populated, includes 
several distinct types: deciduous, mixed, coniferous and boggy associations. The most characteristic forest association is oak-lime-hornbeam (Quercus robur, Tilia cordata, Carpinus betulus). The climate is mostly continental, with cold (1 November-31 March) and warm seasons (1 April-31 October, Jędrzejewska and Jędrzejewski 1998). The forest is inhabited by a rich animal community. Ungulates are represented by five species: European bison Bison bonasus, moose Alces alces, red deer Cervus elaphus, roe deer Capreolus capreolus, and wild boar Sus scrofa, as well as forty species of raptors and carnivores, including wolves and Eurasian lynx Lynx lynx.

Scavenging is a crucial ecological process in Białowieża, as shown by studies conducted since the 1990s in the Polish part of the forest (Jędrzejewska and Jędrzejewski 1998; Selva 2004a). Ungulates constitute the bulk of the carrion supply; about 7-9\% of the standing crop of ungulate biomass is removed by scavengers each year. Ungulate carrion is supplied as wolf and lynx kills, leftovers from hunting, and natural deaths caused by disease or malnutrition. This high "diversity" of ungulate carcasses includes different spatio-temporal availability and features (e.g. size, visibility, openness) of carrion resources. Whereas predator-kills are supplied more or less constantly at unpredictable locations, hunter-kills are more localized and natural deaths mostly appear as a pulse at the end of the winter. Carcasses also vary in how accessible and easy to find and consume they are. For instance, European bison dying from natural conditions can be available for several months in winter as they are often concealed, weigh a few hundred $\mathrm{kg}$, and are hard to open and find (Selva et al. 2005). Small roe deer, perfectly camouflaged and guarded by lynx, also are not easily accessible to many scavengers. However, red deer killed by wolves are often partly consumed, covered in blood, and easy to find, take away, and consume, typically disappear quickly (Selva 2004a, b).

This "diversity" of carrion resources has facilitated different mechanisms of coexistence among the numerous species of scavengers and promoted a structured (nested) use of carrion resources (Selva 2004a, Selva and Fortuna 2007). Thirty-six species of birds and mammals were reported using carrion in Białowieża (Selva 2004a). Predator-kills were preferred by most scavengers, but predation risk, namely intraguild predation, clearly influenced the carcass choice by some species. Ravens, foxes, and pine martens selected wolf kills when scavenging, but less frequently used the guarded prey of lynx; lynx have often been reported to kill foxes and martens (Jędrzejewska and Jędrzejewski 1998; Palomares and Caro 1999). Raptors generally preferred to scavenge in open areas, and were frequent at hunters' kills. Ravens and foxes, present in 89 and $86 \%$ of the wolf-kills respectively, were documented to follow wolves on the ground and in the air to feed on their prey remains (Jędrzejewska and Jędrzejewski 1998). Dead ungulates were the least attractive to scavengers and show the lowest species richness. This may be related not only to difficulties in finding and opening carcasses, but also to the risk of disease and parasite transmission and the unpredictability of this carrion resource (Selva 2004a).

Apart from scavengers' preferences in relation to various types of carrion resources, other mechanisms of segregation structure the scavenging guild in Białowieża Forest (Selva 2004a). In particular, a clear temporal segregation among 
avian and mammalian scavengers, mostly active during the day and night respectively, exists. Scavengers also follow a sequence of arrival at carcasses, with ravens and foxes arriving first in most cases. Habitat heterogeneity also appears to promote scavenger coexistence (Selva 2004a). Pine martens and jays avoided carcasses in open areas, whereas raptors preferred them. All scavengers avoided carcasses located near villages. Weather conditions, namely temperature and snow cover, played a key role in mediating carcass use (Selva et al. 2005). In general, more species scavenged at lower temperatures and in deeper snow, reflecting the higher energetic requirements and lower availability of other food resources, like rodents, in winter. For instance, at cold temperatures and deep snow, pine marten reduce their activity and increases food intake, typically by staying close to and feeding on ungulate carcasses (Zalewski et al. 1995; Zalewski 2000) Therefore, carcass use by scavenger species varied seasonally with summer carcasses mostly consumed by invertebrates and decomposers. Among vertebrates, only the raccoon dog Nyctereutes procyonoides scavenged more frequently in summer than winter (Selva 2004a).

Ungulate carrion served as a crucial food resource for the vertebrate community in winter (Jędrzejewska and Jędrzejewski 1998; Selva 2004a). The decline of food resources and increased persistence of carrion during winter resulted in increased use of ungulate carcasses at the end of the cold season by medium-sized and small predators. For example, the proportion of rodents in pine marten diet decreased through the winter, while the consumption of ungulate carcasses increased, reaching a maximum in February (Jędrzejewski et al. 1993). The scavenger assemblage also was more nested in the cold season, with a more structured pattern of use observed at carcasses that were constantly supplied, either by large predators or by hunters (Selva and Fortuna 2007). Competition, particularly intraspecific, at ungulate carcasses was strong. Simultaneous feeding by different species at carcasses was uncommon and the monopoly of the carcass by a single species was prevalent (Selva 2004a). In general, dominant species arrived later than scavengers with a lower hierarchical rank. Facilitative interactions were also documented, particularly at intact ungulate carcasses. Wolves extensively used bison carcasses and were the only species able to open them and provide further access to other species. Scavenging by wolves at bison carcasses always triggered scavenging by mesopredators (Selva et al. 2003).

Ungulate carcasses also had relevant effects on other components of the ecosystem, such as soil, vegetation, and alternative prey species (Melis et al. 2007; CortésAvizanda et al. 2009). Most carcass-derived nutrients are recycled via scavenging and therefore transferred by vertebrates to distant areas. Higher nutrient concentrations were found in the areas surrounding bison carcasses (up to $4 \mathrm{~m}$ ), an effect which lasted up to 7 years after the death of the animal (Melis et al. 2007). However, the impact was not as dramatic as in other more homogeneous systems, such as tundra or prairie ecosystems, possibly due to the high scavenging activity and forest complexity of Białowieża Primeval Forest. Large carcasses also affected apparently distant trophic levels, such as herbivores, via facultative scavengers (CortésAvizanda et al. 2009) as these scavengers, which are also predators, aggregated at 
carcasses. For example, the probability of predator-prey encounters was significantly higher within the vicinity of carcasses (1-km radius). This was accompanied by a reduced presence of hares Lepus europaeus and other alternative prey, such as red squirrels Sciurus vulgaris, close to carcasses, probably as a consequence of direct killing and/or predator avoidance (Cortés-Avizanda et al. 2009).

\section{Yellowstone National Park: Effect of Large Predators on Scavenger Communities Through Provisioning of Carrion}

Yellowstone is well-known as the first National Park in North America. The landscape is dominated by large open valleys and shrub steppes, and coniferous forests at north slopes and higher elevations, which range from 1500 to $3400 \mathrm{~m}$ (Houston 1982). In winter, ungulates concentrate in large aggregations along the Yellowstone River drainage. Eight species of ungulates (elk Cervus canadensis, mule deer Odocoileus hemionus, white-tailed deer, moose, American bison Bison bison, bighorn sheep Ovis canadensis, pronghorn antelope Antilocapra americana, and the mountain goat Oreamnos americanus) coexist with five species of large carnivores (coyote, wolf, cougar Puma concolor, grizzly bear, and black bear U. americanus). Long cold snowy winters and short cool summers characterize the climate. Mean monthly temperatures range from -12 to $+13{ }^{\circ} \mathrm{C}$ (Cook 1993). The Yellowstone ecosystem is one of the best studied ecosystems in the world and the reintroduction of wolves in 1995 has been a milestone in wildlife conservation and a natural experiment to investigate the role of large predators as carrion suppliers, and the induced trophic cascades and changes in scavenger communities.

An important change for scavengers brought by wolf restoration has been the alteration of the quantity and timing of carrion availability (Fig. 5; Wilmers et al. 2003a). Before wolf reintroduction, the mortality of elk, the most abundant ungulate, depended on the snow depth and, thus, carrion was plentiful during severe winters, but scarce during mild winters (Houston 1978). Now, wolves are the main cause of elk mortality in Yellowstone, and have changed the timing of ungulate carrion from a sudden pulse at the end of winter to a more constant resource throughout the year. Although they may lower the total amount of carrion available, wolves have reduced the temporal variation in the quantity of carrion and extended the period over which carrion is available (Wilmers et al. 2003a, Wilmers and Getz 2004). Moreover, wolf presence may buffer changes in carrion availability due to climate warming (Wilmers and Getz 2005). By mitigating the reduction in latewinter carrion due to shorter and milder winters, wolves support the adaptation of scavengers to climate change (Wilmers and Getz 2005).

Wolf-provided carrion may promote biodiversity and larger populations of scavenger species (Wilmers et al. 2003a). When compared to hunter kills, highly aggregated in time and space, wolf kills showed higher species diversity (Wilmers et al. 2003b). Bald eagles, golden eagles Aquila chrysaetos, ravens, magpies Pica pica and coyotes were common at wolf kills in Yellowstone whereas coyotes, and mam- 


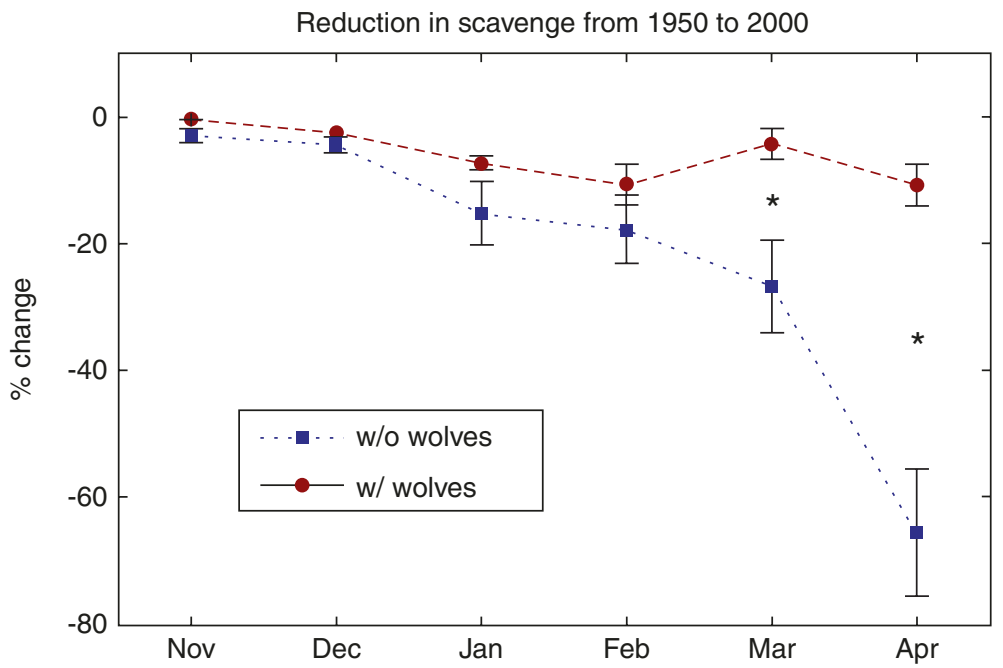

Fig. 5 Statistical model illustrating the extent to which the presence of wolves in Yellowstone National Park (https://goo.gl/maps/TuwcwD9Nd1P2) stabilize carrion availability and thus mitigate effects of climate change. "Reduction in winter carrion available to scavengers due to climate change 1950-2000: statistical model" is reproduced in its entirety from Wilmers and Getz (2005), and is licensed under CC BY 4.0 (https://creativecommons.org/licenses/by/4.0/legalcode)

mals in general, were absent at remains of hunter-kills in the surrounding landscape. Competitively dominant species, like coyotes, dominated scavenging at the more dispersed wolf kills whereas wide-ranging consumers, such as bald eagles and ravens, dominated consumption at highly aggregated hunter kills. However, the total number of individual scavengers at hunter kills exceeded those at wolf kills, likely due to social and information transfer mechanisms that eagles and ravens have developed to better track aggregated resources (Wilmers et al. 2003b). Indeed, ravens have quickly associated with wolves in order to scavenge first on the remains of their kills (Stahler et al. 2002).

The reintroduction of wolves clearly has affected the Yellowstone food web, and therefore, also the scavenger community (Peterson et al. 2014; Dobson 2014). For example, ungulate carrion is a key food for grizzly bears when they emerge from hibernation (Green et al. 1997) and opportunities to scavenge carcasses by grizzly bears have increased since the reestablishment of wolves (Wilmers et al. $2003 a$, b). Wolf-bear interactions, mostly at wolf kill sites, also are now more frequent, with a clear dominance by bears (Smith et al. 2003). Wolf-killed carrion also represents increased opportunities for intraguild predation. Although wolves clearly provide food for coyotes, ungulate carrion sites are risky and 7\% of wolfcoyote interactions ended in coyote death (Merkle et al. 2009). Wolf aggression towards coyotes resulted in a strong decline in coyote densities and pack size in the years following wolf reintroduction (Smith et al. 2003). However, coyotes adapted to the new competitor at carcasses by modifying their behavior and maintaining spatial and temporal separation (Arjo and Pletscher 1999; Switalski 2003; Atwood 
and Gese 2008). In some ungulate species, a decrease in mortality from coyote predation has been reported in Yellowstone subsequent to the reintroduction of wolves (Berger et al. 2008).

Large predator kills and winter kills that are only partly consumed by scavengers are later exploited by insect larvae, which in turn, attract insectivorous birds (Houston 1978). Arthropods are also a main component of carrion food webs. The presence of ungulate carcasses in Yellowstone increases the local richness, abundance and occurrence of beetles (Sikes 1994). A total of 445 species of beetles were recorded at carcasses in Yellowstone, of which 57 were strongly associated to carrion. The family Silphidae ranked first in abundance, due to the species Thanatophilus lapponicus, followed by the family Staphylinidae, the richest in number of species, and the family Carabidae (Sikes 1994).

\section{Impact of Human Activities on Carcass Availability}

In addition to carrion provisioned through "natural" animal deaths (e.g., predator kills, starvation, exposure, diseases), modern humans have affected scavenging dynamics profoundly in both terrestrial and aquatic ecosystems by increasing the number, distribution, and temporal availability of carcasses to scavengers (see chapter "Human-Mediated Carrion: Effects on Ecological Processes"). In terrestrial ecosystems, human activities (e.g., collisions with vehicles, power lines and other structures, hunting) are responsible for billions of animal deaths worldwide, and most of these animals are left available for scavengers (Mateo-Tomás et al. 2015). In a review of cause-specific m ortality of N orth A merican medium- and large-sized mammals, Collins and Kays (2011) found hunting accounted for about $35 \%$ of all mortality. Because hunters often leave inedible or undesirable portions of carcasses in the field, a substantial amount of carrion biomass can result from hunting mammals and birds that support a diverse assemblage of scavengers (Mateo-Tomás et al. 2015). Similarly, collisions with vehicles are responsible for an extensive number of vertebrate deaths in developed nations (Forman et al. 2003), with approximately 9\% of all medium-and large-sized mammals in North America and 89-340 million birds killed annually by vehicle collisions (Collins and Kays 2011; Loss et al. 2014a). Other major human-related causes of vertebrate mortality in terrestrial ecosystems are less obvious than hunting and road mortality, but still significant. Conover et al. (2013) estimated thousands of ungulates die annually in the U.S. from colliding with or being entangled by fences. Nearly seven million birds in the U.S. and Canada also are killed each year by colliding with communication towers (Longcore et al. 2012), and 135-175 million by colliding with power lines (Conover et al. 2013). Further, in the U.S., 1.3-4.0 billion birds are killed each year by domestic cats (many of which are not eaten; Loss et al. 2013a), 365-988 million by collisions with buildings (Loss et al. 2014b), and 140,000-328,000 by wind turbines (Loss et al. 2013b).

Humans also have increased the amount of available carrion biomass in oceans and other aquatic ecosystems (Britton and Morton 1994). For example, many tons 
of fisheries discards ("by-catch") are returned to the water by commercial fishing boats each year globally. The ratio of discarded to harvested fish or other sea life can be as high as 10:1 (Hill and Wassenberg 1990) and most of the animal biomass returned to the water as by-catch is killed or severely injured during fishing operations (Broadhurst et al. 2006). Carrion from fisheries discards can subsidize marine food webs and well-adapted scavengers may increase in number due to the input of large quantities of fisheries discards (Ramsay et al. 1997; Catchpole et al. 2006). However, such carrion subsidies redistribute large quantities of biomass from the ocean floor and water column to the surface, likely altering ecosystem processes linked to nutrient cycling in marine ecosystems. Recreational fishing also can introduce carrion into aquatic ecosystems as mortality of released fish can be considerable (Bartholomew and Bohnsack 2005).

The causes of human-related vertebrate mortality summarized here are not exhaustive; other human activities (e.g., unintentional release of environmental toxins, intentional poisoning) commonly result in vertebrate mortality, and many of these animal carcasses become available to scavengers and decomposers. However, although it is clear human-derived carrion can have profound impacts on animal communities (e.g., Oro et al. 2013) the assimilation of animal carcasses produced as a result of human activities into ecosystems remains poorly characterized. (see chapter "Human-Mediated Carrion: Effects on Ecological Processes" for more information on effects of human-mediated carrion).

\section{Conclusions and Future Perspectives}

Despite a surge in scavenging research over the last few decades, scavenging dynamics and the ecological role of carrion in structuring individual to ecosystem level processes remains an understudied area of ecological research. At the most basic level there remains a paucity of data on scavenging dynamics in many common ecosystem types across the globe, especially island, arctic, tropical, and freshwater aquatic habitats, although many of these landscapes are becoming active areas of research (e.g., Abernethy et al. 2016). There also is a need for more integrative and manipulative research within well studied systems to better elucidate the effects of global change on scavenging dynamics, and the subsequent consequences to nutrient cycling and food web dynamics.

Disruptions to ecological communities due to climate change, overfishing, habitat fragmentation, etc. can alter competitive interactions among microbes, invertebrates, and vertebrates. The consequences of these shifts on scavenging dynamics are largely unknown, but likely profound. Similarly, there is a growing awareness of the potential role of carrion subsidies in the transport of nutrients among ecosystems (e.g., transport of biomass among aquatic ecosystems through disposal of fisheries discards, movement of nutrients sequestered within salmon between freshwater, pelagic, and terrestrial ecosystems), yet the impact of these subsidies on both the ecosystems from which they were removed and those in which they are input have 
not been adequately explored. There also has been extensive discussion of the role scavengers play in the control and dissemination of disease, although this remains an area of much needed research.

It is well established that temperature can have a confounding effect on investigations of carcass persistence and scavenging dynamics (DeVault et al. 2003; Farwig et al. 2014) and as such many researchers now routinely integrate temperature into the experimental design of many carrion fate studies. However, seemingly lost in many investigations of vertebrate scavenging ecology is the role of other potential factors on the composition of vertebrate scavenging communities. Recent research suggests carcass detection rates, persistence, and composition of scavenging communities can be highly influenced by the species and size of carrion (Olson et al. 2016; DeVault et al. 2017), as well as the local habitat type and accessibility of the carcass (Moleón et al. 2015; Turner et al. 2017). Thus, failure to integrate potential confounding factors, in addition to temperature, into experimental designs may bias inference of carrion and fate and scavenging dynamics.

Acknowledgements Contributions of James Beasley were partially supported by the U.S. Department of Energy under Award Number DE-EM0004391 to the University of Georgia Research Foundation.

\section{References}

Abernethy E, Turner K, Beasley JC et al (2016) Carcasses of invasive species are primarily utilized by invasive scavengers in an island ecosystem. Ecosphere 7:e01496

Allen ML, Elbroch LM, Wilmers CC, Wittmer HU (2014) Trophic facilitation or limitation? Comparative effects of pumas and black bears on the scavenger community. PLoS One 9:e102257

Arjo WM, Pletscher DH (1999) Behavioral responses of coyotes to wolf recolonization in northwestern Montana. Can J Zool 77:1919-1927

Atwood TC, Gese EM (2008) Coyotes and recolonizing wolves: social rank mediates riskconditional behaviour at ungulate carcasses. Anim Behav 75:753-762

Avery ML, Cummings JL (2004) Livestock depredations by black vultures and golden eagles. Sheep Goat Res J 19:58-63

Bartholomew A, Bohnsack JA (2005) A review of catch-and-release angling mortality with implications for no-take reserves. Rev Fish Biol Fish 15:129-154

Barton PS, Cunningham SA, Lindenmayer DB, Manning AD (2013) The role of carrion in maintaining biodiversity and ecological processes in terrestrial ecosystems. Oecologia 171:761-772

Beard KH, Pitt WC, Price EA (2009) Biology and impacts of Pacific Island invasive species. 5. Eleutherodactylus coqui, the coqui frog (Anura: Leptodactylidae). Pac Sci 63:297-316

Beasley JC, Olson ZH, Dharmarajan G, Eagan TS II, Rhodes OE Jr (2011) Spatio-temporal variation the demographic attributes of a generalist mesopredator. Landsc Ecol 26:937-950

Beasley JC, Olson ZH, DeVault TL (2012) Carrion cycling in food webs: comparisons among terrestrial and marine ecosystems. Oikos 121:1021-1026

Beasley JC, Olson ZH, Beatty WS, Dharmarajan G, Rhodes OE Jr (2013) Effects of culling on mesopredator populations dynamics. PLoS One 8:e58982

Beasley JC, Olson ZH, DeVault TL (2015) Ecological role of vertebrate scavengers. In: Benbow ME, Tomberlin J, Tarone A (eds) Carrion ecology, evolution, and their application. CRC, Boca Raton, pp 107-128 
Bellan SE, Turnbull PCB, Beyer W, Getz WM (2013) Effects of experimental exclusion of scavengers from carcasses of anthrax-infected herbivores on Bacillus anthracis sporulation, survival, and distribution. Appl Environ Microbiol 79:3756-3761

Benbow EM, Barton P, Ulyshen M, Beasley JC, DeVault TL, Strickland M, Tomberlin J, Jordan H, Pechal J (2019) Necrobiome framework for bridging decomposition ecology of autotrophically and heterotrophically derived organic matter. Ecol Monogr 89:e01331, pp. 1-29

Berger KM, Gese EM, Berger J (2008) Indirect effects and traditional trophic cascades: a test involving wolves, coyotes, and pronghorn. Ecology 89:818-828

Braack LEO (1987) Community dynamics of carrion-attendant arthropods in tropical African woodland. Oecologia 72:402-409

Britton JC, Morton B (1994) Marine carrion and scavengers. Oceanogr Mar Biol Annu Rev 32:369-434

Broadhurst MK, Suuronen P, Hulme A (2006) Estimating collateral mortality from towed fishing gear. Fish Fish 7:180-218

Buckley NJ (1999) Black vulture (Coragyps atratus). In: Poole A (ed) The birds of North America Online, Account 411. Cornell Lab of Ornithology, Ithaca, NY. http://bna.birds.cornell.edu. proxy-remote.galib.uga.edu/bna/species/411

Bump JK, Webster CR, Vucetich JA, Peterson RO, Shields JM, Powers MD (2009a) Ungulate carcasses perforate ecological filters and create biogeochemical hotspots in forest herbaceous layers allowing trees a competitive advantage. Ecosystems 12:996-1007

Bump JK, Peterson RO, Vucetich JA (2009b) Wolves modulate soil nutrient heterogeneity and foliar nitrogen by configuring the distribution of ungulate carcasses. Ecology 90:3159-3167

Butman CA, Carlton JT, Palumbi SR (1995) Whaling effects on deep-sea biodiversity. Conserv Biol 9:462-464

Byrd JH, Castner JL (2010) Forensic entomology: the utility of arthropods in legal investigations. CRC, Boca Raton

Carbone C, Turvey ST, Bielby J (2011) Intra-guild competition and its implications for one of the biggest terrestrial predators, Tyrannosaurus rex. Proc R Soc B 278:2682-2690

Carter DO, Yellowlees D, Tibbett M (2007) Cadaver decomposition in terrestrial ecosystems. Naturwissenschaften 94:12-24

Catchpole TL, Frid CLJ, Gray TS (2006) Importance of discards from the English Nephrops norvegicus fishery in the North Sea to marine scavengers. Mar Ecol Prog Ser 313:215-226

Cederholm CJ, Kunze MD, Murota T, Sibatani A (1999) Pacific salmon carcasses: essential contributions of nutrients and energy for aquatic and terrestrial ecosystems. Fisheries 24:6-15

Coe MJ (1978) The decomposition of elephant carcasses in the Tsavo (East) National Park, Kenya. J Arid Environ 1:71-86

Cohen JE (1978) Food webs and niche space. Princeton University Press, Princeton, NJ

Cohen JE, Briand F, Newman CM (1990) Community food webs: data and theory. Springer, New York

Collins C, Kays R (2011) Causes of mortality in North American populations of large and mediumsized mammals. Anim Conserv 14:474-483

Conover MR, Dinkins JB, Haney MJ (2013) Impacts of weather and accidents on wildlife. In: Wildlife management and conservation: contemporary principles and practices. Johns Hopkins University Press, Baltimore, MD, pp 144-155

Cook RS (1993) Ecological issues on reintroducing wolves into Yellowstone National Park. US Department of the Interior, National Park Service Scientific Monograph

Cornaby BW (1974) Carrion reduction by animals in contrasting tropical habitats. Biotropica 6:51-63

Cortés-Avizanda A, Selva N, Carrete M, Donázar JA (2009) Effects of carrion resources on herbivore spatial distribution are mediated by facultative scavengers. Basic Appl Ecol 10: 265-272

Cortés-Avizanda A, Jovani R, Carrete M, Donázar JA (2012) Resource unpredictability promotes species diversity and coexistence in an avian scavenger guild: a field experiment. Ecology 93:2570-2579 
De Angelis DL (1975) Stability and connectance in food web models. Ecology 56:238-243

DeVault TL, Rhodes OE Jr, Shivik JA (2003) Scavenging by vertebrates: behavioral, ecological, and evolutionary perspectives on an important energy transfer pathway in terrestrial ecosystems. Oikos 102:225-234

DeVault TL, Reinhart BD, Brisbin IL Jr, Rhodes OE Jr (2004) Home ranges of sympatric black and turkey vultures in South Carolina. Condor 106:706-711

DeVault TL, Olson ZH, Beasley JC, Rhodes OE Jr (2011) Mesopredators dominate competition for carrion in an agricultural landscape. Basic Appl Ecol 12:268-274

DeVault TL, Beasley JC, Olson ZH, Moleón M, Carrete M, Margalida A, Sánchez-Zapata JA (2016) Ecosystem services provided by avian scavengers. In: Şekercioğlu CH, Wenny DG, Whelan CJ (eds) Why do birds matter? Avian ecological function and ecosystem services. University of Chicago Press, pp 235-270

DeVault TL, Seamans TW, Linnell KE, Sparks DW, Beasley JC (2017) Scavenger removal of bird carcasses at simulated wind turbines: Does carcass type matter? Ecosphere 8(11):e01994

Dobson AP (2014) Yellowstone wolves and the forces that structure natural systems. PLoS Biol 12:e1002025

Dunne JA (2006) The network structure of food webs. In: Pascual M, Dunne JA (eds) Ecological networks: linking structure to dynamics in food webs. Oxford University Press, Oxford, pp 27-86

Dunne JA, Williams RJ, Martínez ND (2002) Food-web structure and network theory: the role of connectance and size. Proc Natl Acad Sci U S A 99:12917-12922

Elton C (1927) Animal ecology. Sidgwick and Jackson, London

Fahrig L (2003) Effects of habitat fragmentation on biodiversity. Annu Rev Ecol Evol Syst 34:487-515

Fallows C, Gallagher AJ, Hammerschlag N (2013) White sharks (Carcharodon carcharias) scavenging on whales and its potential role in further shaping the ecology of an apex predator. PLoS One 8:e60797

Farwig N, Brandl R, Siemann S, Wiener F, Müller J (2014) Decomposition rate of carrion is dependent on composition not abundance of the assemblages of insect scavengers. Oecologia 175:1291-1300

Forman RTT, Sperling D, Bissonette JA, Clevenger AP, Cutshall CD, Dale VH, Fahrig L, France RL, Goldman CR, Haanue K, Jones J, Swanson F, Turrentine T, Winter TC (2003) Road ecology: science and solutions. Island Press, Washington

Fuglei E, Øritsland NA, Prestrud P (2003) Local variation in arctic fox abundance on Svalbard, Norway. Polar Biol 26:93-98

Gasaway WC, Mossestad KT, Stander PE (1991) Food acquisition by spotted hyenas in Etosha National Park, Namibia: predation versus scavenging. African J Ecol 29:64-75

Gende SM, Edwards RT, Willson MF, Wipfli MS (2002) Pacific salmon in aquatic and terrestrial ecosystems. Bioscience 52:917-928

Gende SM, Quinn TP, Hilborn R, Hendry AP, Dickerson B (2004) Brown bears selectively kill salmon with higher energy content but only in habitats that facilitate choice. Oikos 104:518-528

Gese EM, Ruff RL, Crabtree RL (1996) Foraging ecology of coyotes (Canis latrans): the influence of extrinsic factors and a dominance hierarchy. Can J Zool 74:769-783

Gooday AJ, Turley CM, Allen JA (1990) Responses by benthic organisms to inputs of organic material to the ocean floor: a review. Philos Trans R Soc Lond Ser B Biol Sci 331:119-138

Green GI, Mattson DJ, Peek JM (1997) Spring feeding on ungulate carcasses by grizzly bears in Yellowstone National Park. J Wildl Manag 61:1040-1055

Green RE, Newton I, Shultz S, Cunningham AA, Gilbert M, Pain DJ, Prakash V (2004) Diclofenac poisoning as a cause of vulture population declines across the Indian subcontinent. J Appl Ecol 41:793-800

Hanski I, Kuusela S (1980) The structure of carrion fly communities: differences in breeding seasons. Ann Zool Fenn 17:185-190

Heinrich B, Pepper JW (1998) Influence of competitors on caching behavior in the common raven, Corvus corax. Anim Behav 56:1083-1090 
Helfield JM, Naiman RJ (2006) Keystone interactions: salmon and bear in riparian forests of Alaska. Ecosystems 9:167-180

Hertel F (1994) Diversity in body size and feeding morphology within past and present vulture assemblages. Ecology 75:1074-1084

Hill BJ, Wassenberg TJ (1990) Fate of discards from prawn trawlers in Torres strait. Aust J Marine Freshwater Res 41:53-64

Hill JE, DeVault TL, Beasley JC, Rhodes OE Jr, Belant JL (2018) Effects of vulture exclusion on carrion consumption by facultative scavengers. Ecol Evol 8(5):2518-2526

Hocking MD, Reynolds JD (2011) Impacts of salmon on riparian plant diversity. Science 331:1609-1612

Hocking MD, Ring RA, Reimchen TE (2009) The ecology of terrestrial invertebrates on Pacific salmon carcasses. Ecol Res 24:1091-1100

Houston DB (1978) Elk as winter-spring food for carnivores in northern Yellowstone National Park. J Appl Ecol 15:653-661

Houston DC (1979) The adaptations of scavengers. In: Sinclair ARE, Griffiths NM (eds) Serengeti, dynamics of an ecosystem. University of Chicago Press, Chicago, pp 263-286

Houston DB (1982) The northern Yellowstone elk: ecology and management. Macmillan, New York

Houston D, Cooper J (1975) The digestive tract of the whiteback griffon vulture and its role in disease transmission among wild ungulates. J Wildl Dis 11:306-313

Hutchinson G (1957) Concluding remarks. Cold Spring Harb Symp Quant Biol 22:415-427

Janzen D (1977) Why fruits rot, seeds mold, and meat spoils. Am Nat 111:691-713

Jędrzejewska B, Jędrzejewski W (1998) Predation in vertebrate communities. The Białowieża Primeval Forest as a case study. Springer, Berlin

Jędrzejewski W, Zalewski A, Jędrzejewska B (1993) Foraging by pine marten Martes martes in relation to food resources in Białowieża National Park, Poland. Acta Theriol 38:405-426

Jennelle C, Samuel MD, Nolden CA, Berkley EA (2009) Deer carcass decomposition and potential scavenger exposure to chronic wasting disease. J Wildl Manag 73:655-662

Johnson SB, Warén A, Lee RW, Kano Y, Kaim A, Davis A, Strong EE, Vrjenhoek RC (2010) Rubyspira, new genus and two new species of bone-eating deep-sea snails with ancient habits. Biol Bull 219:166-177

Kaiser MJ, Moore PG (1999) Obligate marine scavengers: do they exist? J Nat Hist 33:475-481

Killengreen ST, Strømseng E, Yoccoz NG, Ims RA (2012) How ecological neighbourhoods influence the structure of the scavenger guild in low arctic tundra. Divers Distrib 18:563-574

Kirk DA, Mossman MJ (1998) Turkey vulture (Cathartes aura). Account 339 in Poole A (ed) The Birds of North America Online. Cornell Lab of Ornithology, Ithaca, NY. http://bna.birds. cornell.edu.proxy-remote.galib.uga.edu/bna/species/339

Kruuk H (1967) Competition for food between vultures in East Africa. Ardea 55:171-193

Lafferty KD, Dobson AP, Kuris AM (2006) Parasites dominate food web links. Proc Natl Acad Sci U S A 103:11211-11216

Lam K, Babor D, Duthie B, Babor EM, Moore M, Gries G (2007) Proliferating bacterial symbionts on house fly eggs affect oviposition behavior of adult flies. Ani Behav 74:81-92

Lawton J (1989) Food webs. In: Cherrett J (ed) Ecological concepts. Blackwell Scientific, Oxford, pp 43-78

Levi T, Wheat RE, Allen JM, Wilmers CC (2015) Differential use of salmon by vertebrate consumers: implications for conservation. PeerJ 3:e1157. https://doi.org/10.7717/peerj.1157

Lindeman RL (1942) The trophic-dynamic aspect of ecology. Ecology 23:399-417

Linnell JD, Ronny A, Reidar A (1995) Who killed bambi? The role of predation in the neonatal mortality of temperate ungulates. Wildl Biol 1:209-223

Longcore T, Rich C, Mineau P, MacDonald B, Bert DG, Sullivan LM, Mutrie M, Gauthreaux SA Jr, Avery ML, Crawford RL, Manville AM II, Travis ER, Drake D (2012) An estimate of avian mortality at communication towers in the United States and Canada. PLoS One 7:e34025

Loss SR, Will T, Marra PP (2013a) The impact of free-ranging domestic cats on wildlife of the United States. Nat Commun 4:1396 
Loss SR, Will T, Marra PP (2013b) Estimates of bird collision mortality at wind facilities in the contiguous United States. Biol Conserv 168:201-209

Loss SR, Will T, Marra PP (2014a) Estimation of bird-vehicle collision mortality on U.S. roads. J Wildl Manag 78:763-771

Loss SR, Will T, Loss SS, Marra PP (2014b) Bird-building collisions in the United States: estimates of annual mortality and species vulnerability. Condor 116:8-23

Lowney MS (1999) Damage by black and turkey vultures in Virginia, 1990-1996. Wildl Soc Bull 27:715-719

Magoun AJ (1976) Summer scavenging activity in northeastern Alaska. MS thesis, University of Alaska, Fairbanks

Margalida A, Bertran J, Heredia R (2009) Diet and food preferences of the endangered Bearded Vulture Gypaetus barbatus: a basis for their conservation. Ibis 151:235-243

Margalida A, Campión D, Donázar JA (2014) Vultures vs. livestock: conservation relationships in an emerging conflict between humans and wildlife. Oryx 48:172-176

Markandya A, Taylor T, Longo A, Murty MN, Murty S, Dhavala K (2008) Counting the cost of vulture decline - an appraisal of the human health and other benefits of vultures in India. Ecol Econ 67:194-204

Martínez ND (1991) Artifacts or attributes? Effects of resolution on the Little Rock Lake food web. Ecol Monogr 61:367-392

Mateo-Tomás P, Olea PP, Moleón M, Vicente J, Botella F, Selva N, Viñuela J, Sánchez-Zapata JA (2015) From regional to global patterns in vertebrate scavenger communities subsidized by big game hunting. Divers Distrib 21:913-924

May RM (1972) Will a large complex system be stable? Nature 238:413-414

McCann K, Hastings A, Huxel GR (1998) Weak trophic interactions and the balance of nature. Nature 395:794-798

McKinnerney M (1978) Carrion communities in the northern Chihuahuan Desert. Southwest Nat 23:563-576

Melis C, Teurlings I, Linnell JDC, Andersen R, Bordoni A (2004) Influence of a deer carcass on Coleopteran diversity in a Scandinavian boreal forest: a preliminary study. Eur J Wildl Res 50:146-149

Melis C, Selva N, Teurlings I, Skarpe C, Linnell JDC, Andersen R (2007) Soil and vegetation nutrient response to bison carcasses in Białowieża Primeval Forest, Poland. Ecol Res 22:807-813

Merkle JA, Stahler DA, Smith DW (2009) Interference competition between gray wolves and coyotes in Yellowstone National Park. Can J Zool 87:56-63

Moleón M, Sánchez-Zapata JA, Sebastián-González E, Owen-Smith N (2015) Carcass size shapes the structure and functioning of an African scavenging assemblage. Oikos 124:1391-1403

Moore JE, Swihart RK (2005) Modeling patch occupancy by forest rodents: incorporating detectability and spatial autocorrelation with hierarchically structured data. J Wildl Manag 69:933-949

Müller JK, Eggert AK, Dressel J (1990) Intraspecific brood parasitism in the burying beetle, Nicrophorus vespilloides (Coleoptera: Silphidae). Anim Behav 40:491-499

Neutel AM, Heesterbeek JA, de Ruiter PC (2002) Stability in real food webs: weak links in long loops. Science 296:1120-1123

Oaks JL, Gilbert M, Virani MZ, Watson RT, Meteyer CU, Rideout BU, Shivaprasad HL, Ahmed S, Chaudhry MJI, Arshad M, Mahmood S, Ali A, Khan AA (2004) Diclofenac residues as the cause of vulture population decline in Pakistan. Nature 427:630-633

Ogada DL, Keesing F, Virani MZ (2012a) Dropping dead: causes and consequences of vulture population declines worldwide. Ann N Y Acad Sci 1249:57-71

Ogada DL, Torchin ME, Kinnaird MF, Ezenwa VO (2012b) Effects of vulture declines on facultative scavengers and potential implications for mammalian disease transmission. Conserv Biol 26:453-460

Olson ZH, Beasley JC, DeVault TL, Rhodes OE Jr (2012) Scavenger community response to the removal of a dominant scavenger. Oikos 121:77-84 
Olson ZH, Beasley JC, Rhodes OE Jr (2016) Carcass type affects local scavenger guilds more than habitat connectivity. PLoS One 11:e147798

Oro D, Genovart M, Tavecchia G, Fowler MS, Martínez-Abrain A (2013) Ecological and evolutionary implications of food subsidies from humans. Ecol Lett 16:1501-1514

Pain DJ, Cunningham AA, Donald PF, Duckworth JW, Houston DC, Katzner T, Parry-Jones J, Poole C, Prakash V, Round P, Timmins R (2003) Causes and effects of temporospatial declines of Gyps vultures in Asia. Conserv Biol 17:661-671

Palomares F, Caro TM (1999) Interspecific killing among mammalian carnivores. Am Nat 153:492-508

Parmenter R, MacMahon J (2009) Carrion decomposition and nutrient cycling in a semiarid shrubsteppe ecosystem. Ecol Monogr 79:637-661

Payne JA (1965) A summer carrion study of the baby pig Sus scrofa Linnaeus. Ecology 46: 592-602

Pechal JL, Benbow EM, Crippen TL, Tarone AM, Tomberlin JK (2014) Delayed insect access alters carrion decomposition and necrophagous insect community assembly. Ecosphere 5(4):45

Peterson RO, Vucetich JA, Bump JM, Smith DW (2014) Trophic cascades in a multicausal world: Isle Royale and Yellowstone. Annu Rev Ecol Evol Syst 45:325-345

Pimm SL (1982) Food webs. Chapman and Hall, New York

Polis GA (1991) Complex trophic interactions in deserts: an empirical critique of food-web theory. Am Nat 138:123-155

Prakash V, Pain DJ, Cunningham AA, Donald PF, Prakash N, Verma A, Gargi R, Sivakumar S, Rahmani AR (2003) Catastrophic collapse of Indian white-backed Gyps bengalensis and longbilled Gyps indicus vulture population. Biol Conserv 109:381-390

Prugh LR, Stoner CJ, Epps DW, Bean WR, Ripple WJ, Laliberte AS, Brashares JS (2009) The rise of the mesopredator. Bioscience 59:779-791

Ramsay K, Kaiser MJ, Moore PG, Hughes RN (1997) Consumption of fisheries discards by benthic scavengers: utilization of energy subsidies in different marine habitats. J Anim Ecol 66:884-896

Restani M, Harmata AR, Madden EM (2000) Numerical and functional responses of migrant bald eagles exploiting a seasonally concentrated food source. Condor 102:561-568

Roggenbuck M, Schnell IB, Blom N, Baelum J, Bertelsen MF, Pontén TS, Sørensen SJ, Gilbert MTP, Graves GR, Hansen LH (2014) The microbiome of New World vultures. Nat Commun 5:5498

Rooney TP, Waller DM (2003) Direct and indirect effects of white-tailed deer in forest ecosystems. For Ecol Manag 181:165-176

Rose MD, Polis GA (1998) The distribution and abundance of coyotes: the effects of allochthonous food subsidies from the sea. Ecology 79:998-1007

Roth JD (2003) Variability in marine resources affects arctic fox population dynamics. J Anim Ecol 72:668-676

Rouse GW, Goffredi SK, Vrijenhoek RC (2004) Osedax: Bone-eating marine worms with dwarf males. Science 305:668-671

Ruxton GD, Bailey DM (2005) Searching speeds and the energetic feasibility of an obligate whalescavenging fish. Deep Sea Res Part 1 Oceanogr Res Pap 52:1536-1541

Ruxton GD, Houston DC (2003) Could Tyrannosaurus rex have been a scavenger rather than a predator? An energetics approach. Proc R Soc Lond B Biol Sci 270:731-733

Ruxton GD, Houston DC (2004a) Obligate vertebrate scavengers must be large soaring fliers. J Theor Biol 228:431-436

Ruxton GD, Houston DC (2004b) Energetic feasibility of an obligate marine scavenger. Mar Ecol Prog Ser 266:59-63

Schlichting PE, Love CN, Webster SC, Beasley JC (2019) Efficiency and composition of vertebrate scavengers at the land-water interface in the Chernobyl Exclusion Zone. Food Webs 18:e0107

Schmitz OJ, Hambäck PA, Beckerman AP (2000) Trophic cascades in terrestrial systems: a review of the effects of top carnivore removals on plants. Am Nat 155:141-153 
Sebastián-González M, Sánchez-Zapata JA, Donazar JA, Selva N, Cortéz-Avizanda A, Hiraldo F, Blázquez M, Botella F, Moleón M (2013) Interactive effects of obligate scavengers and scavenger community richness on lagomorph carcass consumption patterns. Ibis 155:881-885

Sebastián-González E, Moleón M, Gibert JP, Botella F, Mateo-Tomás P, Olea PP, Guimarães PR Jr, Sánchez-Zapata JA (2016) Nested species-rich networks of scavenging vertebrates support high levels of interspecific competition. Ecology 97:95-105

Selva N (2004a) The role of scavenging in the predator community of Białowieża Primeval Forest (E Poland). PhD thesis, University of Sevilla, Spain

Selva N (2004b) Life after death - scavenging on ungulate carcasses. In: Jędrzejewska B, Wójcik JM (eds) Essays on mammals of Białowieża Forest. Mammal Research Institute, PAS, Białowieża, pp 59-68

Selva N, Fortuna MA (2007) The nested structure of a scavenger community. Proc R Soc Lond B Biol Sci 274:1101-1108

Selva N, Jędrzejewska B, Jędrzejewski W, Wajrak A (2003) Scavenging on European bison carcasses in Bialowieza Primeval Forest (eastern Poland). Ecoscience 10:303-311

Selva N, Jędrzejewska B, Jẹdrzejewski W, Wajrak A (2005) Factors affecting carcass use by a guild of scavengers in European temperate woodland. Can J Zool 83:1590-1601

Shivik JA (2006) Are vultures birds, and do snakes have venom, because of macro- and microscavenger conflict? Bioscience 56:819-823

Shivik JA, Clark L (1999) Ontogenetic shifts in carrion attractiveness to brown tree snakes (Boiga irregularis). J Herpetol 33:334-336

Sikes DS (1994) Influences of ungulate carcasses on coleopteran communities in Yellowstone National Park, USA. MS thesis, Montana State University, Montana

Smith CR, Baco AR (2003) Ecology of whale falls at the deep-sea floor. Oceanogr Mar Biol Annu Rev 41:311-354

Smith DW, Peterson RO, Houston DB (2003) Yellowstone after Wolves. Bioscience 53:330-340

Smith CR, De Leo FC, Bernardino AF, Sweetman AK, Arbizu PM (2008) Abyssal food limitation, ecosystem structure and climate change. Trends Ecol Evol 23:518-528

Stahler D, Heinrich B, Smith D (2002) Common ravens, Corvus corax, preferentially associate with grey wolves, Canis lupus, as a foraging strategy in winter. Anim Behav 64:283-290

Swift MJ, Heal OW, Anderson JM (1979) Decomposition in terrestrial ecosystems. Blackwell, Oxford

Switalski TA (2003) Coyote foraging ecology and vigilance in response to gray wolf reintroduction in Yellowstone National Park. Can J Zool 81:985-993

Tamburri MN, Barry JP (1999) Adaptations for scavenging by three diverse bathyla species, Eptatretus stouti, Neptunea amianta and Orchomene obtusus. Deep Sea Res 46(Pt 1):2079-2093

Tilman D (1996) Biodiversity: population versus ecosystem stability. Ecology 77:350-363

Tomberlin JK, Sheppard DC, Joyce JA (2005) Black soldier fly (Diptera: Stratiomyidae) colonization of pig carrion in South Georgia. J Forensic Sci 50:JFS2003391-2

Towne EG (2000) Prairie vegetation and soil nutrient responses to ungulate carcasses. Oecologia 122:232-239

Turner KL, Abernethy EF, Conner LM, Rhodes OE Jr, Beasley JC (2017) Abiotic and biotic factors modulate carrion fate and scavenging community dynamics. Ecology 98:2413-2424

VanLaerhoven S (2010) Ecological theory and its application in forensic entomology. In: Byrd J, Castner J (eds) Forensic entomology: the utility of arthropods in legal investigations. CRC Press, Boca Raton, pp 493-518

VerCauteren KC, Pilon JL, Nash PB, Phillips GE, Fischer JW (2012) Prion remains infectious after passage through digestive system of American crows (Corvus brachyrhynchos). PLoS One 7:e45774

Wardle DA, Bardgett RD, Klironomos JN, Setala H, van der Putten WH, Wall DH (2004) Ecological linkages between aboveground and belowground biota. Science 304:1629-1633

Wasserman S, Faust K (1994) Social network analysis: Methods and applications, vol 8. Cambridge University Press, Cambridge 
Whitaker JO Jr, Mumford RE (2010) Mammals of Indiana. Revised an. Indiana University Press, Bloomington

Wikenros C, Sand H, Ahlqvist P, Liberg O (2013) Biomass flow and scavengers use of carcasses after re-colonization of an apex predator. PLoS One 8(10):e77373

Wilmers CC, Getz WM (2004) Simulating the effects of wolf-elk population dynamics on resource flow to scavengers. Ecol Model 177:193-208

Wilmers CC, Getz WM (2005) Gray wolves as climate change buffers in Yellowstone. PLoS Biol 3:e92

Wilmers CC, Crabtree RL, Smith DW, Murphy KM, Getz WM (2003a) Trophic facilitation by introduced top predators: grey wolf subsidies to scavengers in Yellowstone National Park. J Anim Ecol 72:909-916

Wilmers CC, Stahler DR, Crabtree RL, Smith DW, Getz WM (2003b) Resource dispersion and consumer dominance: scavenging at wolf- and hunter-killed carcasses in Greater Yellowstone, USA. Ecol Lett 6:996-1003

Wilson EE, Wolkovich EM (2011) Scavenging: how carnivores and carrion structure communities. Trends Ecol Evol 26:129-135

Yang LH (2004) Periodical cicadas as resource pulses in North American forests. Science 306:1565-1567

Zalewski A (2000) Factors affecting the duration of activity by pine martens (Martes martes) in the Białowieża National Park, Poland. J Zool 251:439-447

Zalewski A, Jędrzejewski W, Jędrzejewska B (1995) Pine marten home ranges, numbers and predation on vertebrates in a deciduous forest (Białowieża National Park, Poland). Ann Zool Fenn 32:131-144

Zheng L, Crippen TL, Holmes L, Singh B, Pimsler ML, Benbow ME, Tarone AM, Dowd S, Yu Z, Vanlaerhoven SL, Wood TK, Tomberlin JK (2013) Bacteria mediate oviposition by the black soldier fly, Hermetia illucens (L.), (Diptera: Stratiomyidae). Sci Reports 3:2563 